\title{
Conservación de piedra petroglifo y lito esculturas del parque lítico de Huaraz - Ancash ${ }^{1}$
}

\section{Conservation of petroglyph stone and lithic sculptures of the Hua- raz lithic park - Ancash}

\author{
Donal Mauricio Gutiérrez Espinola \\ https://orcid.org/oooo-0002-9776-2938 \\ Ministerio de Cultura \\ donalgutierreze@gmail.com
}

\section{RESUMEN}

Esta, es una descripción del proyecto de conservación de dos lito esculturas, un monolito de la Cultura Recuay y el petroglifo mundialmente conocido como "La Piedra Isabelita", atribuido al formativo temprano, encontrada en Cotojirca, Mareniyoc, Jangas, Ancash. Todos ellos actualmente ubicados en el Parque lítico, del Museo de Huaraz, Ancash. El proyecto se basó en recomendaciones, principios y la práctica sobre conservación lítica. Exponemos aquí la documentación gráfica-fotográfica, diagnóstico y sus causas de deterioro. Se incluye la metodología del registro, procesos y criterios técnicos de conservación. Se incide en la intervención del Petroglifo Isabelita incluyendo su análisis técnico, iconográfico e iconológico, basado en la publicación realizada por su descubridor, el Lic. Víctor Ponte. Su importancia está dada en el aspecto contextual - ceremonial de esta roca, por el lugar donde fue ubicado. Se concluye con recomendaciones sobre el lugar donde se encuentra actualmente expuesto.

Palabras clave: Conservación; lito escultura; Isabelita; Huaraz.

\footnotetext{
1. La base de esta publicación es producto del contrato realizado con la empresa JM. IGENIEROS E.I.R.L, responsable de la construcción del Centro Cultural de Huaraz, por encargo de la Municipalidad de Huaraz y a propuesta de la Dirección Desconcentra del Ministerio de Cultura de Ancash, el mismo que por incumplimiento del pago, no se entregó el Informe Final que aquí se desarrolla. La labor se realizó entre junio-agosto de 2012.
} 


\section{ABSTRACT}

This is a description of the conservation project of two litho sculptures, a monolith of the Recuay Culture and the petroglyph known worldwide as "La Piedra Isabelita", attributed to the early formative, found in Cotojirca, Mareniyoc, Jangas, Ancash. All of them currently located in the lithic park, of the Huaraz Museum, Ancash. The project was based on recommendations, principles and practice on lithic conservation. We present here the graphic-photographic documentation, diagnosis and its causes of deterioration. The registration methodology processes and technical conservation criteria are included. It focuses on the intervention of the Petroglyph Isabelita including its technical, iconographic and iconological analysis, based on the publication made by its discoverer, Lic. Víctor Ponte. Its importance is given in the contextual-ceremonial aspect of this rock, by the place where it was located. It concludes with recommendations on the place where it is currently exposed.

Keywords: Conservation; litho sculpture; Isabelita; Huaraz.

ReCiBIDO: 09/09/2020 - ACEPTADO: 24/09/2020 - PubLICADO: 10/05/2021

\section{INTRODUCCIÓN}

Las lito esculturas que actualmente se encuentra expuesto en el Parque Lítico del Museo de Huaraz, provienen de diferentes lugares del ámbito del departamento de Huaraz y en su mayoría son manifestaciones artísticas pertenecientes a la cultura Recuay y Jangas. Los arqueólogos suponen que "La Piedra Isabelita", representa una escena religiosa de invocación a la lluvia. El descubrimiento formó parte de los vestigios encontrados durante la etapa de construcción de una vía de la mina Pierina.

\section{LA CONSERVACIÓN EN PIEDRA}

Nuestra labor se basó en los principios internacionales de conservación plasmados en la Carta de Venecia (1964), la Carta Internacional para la Gestión del Patrimonio Arqueológico (ICOMOS 1990) y en los procedimientos de análisis de los institutos de investigación de conservación internacionales. Además; para la conservación en piedra, nos basamos en las recomendaciones de la Carta del Restauro (1972), y la Carta de la Conservación y restauración de los Objetos de Arte y Cultura (1987).

Somos conscientes en indicar, que para la intervención de una obra de arte como bien parte integrante del bien cultural pre hispánico, se debe cumplir con las fases de una intervención clínica, como son; la anamnesis, el diagnóstico, la prognosis, el tratamiento, el monitoreo, el coste e informe, desarrollados con todos sus elementos constitutivos. No obstante, al ser el objetivo de este proyecto la conservación y eliminación de fragua de cemento, líquenes, moho y esporas, adherido a los elemen- 
tos de las lito esculturas, monolito y el petroglifo, consideramos solo el diagnóstico, por ser un elemento de suma importancia poder saber el costo real en los proyectos de conservación, por lo que es necesario seguir, las recomendaciones contenidas en la Carta de Zimbabue (2003).

Como parte de anamnesis, se realizó la documentación histórica, gráfica y fotográfica, en forma detallada determinando las condiciones de humedad, filtraciones, condensaciones, capilaridad y adherencia de la fragua de cemento y ataques biológicos y químicos. No se hizo análisis microbiológicos.

Debido a las caracterizas de este trabajo, sólo realizamos parte de del diagnóstico, como fue la evaluación y el registro. En la evaluación, establecimos la relación entre las manifestaciones del deterioro específico y los dispositivos que la produjeron, lo que nos facilitó el poder realizar la identificación y el reconocimiento de las principales causas y los mecanismos de alteración existentes en estos bienes, y plantear las soluciones específicas para una correcta conservación de las lito esculturas, monolito y petroglifo en estudio. Para ello, se tuvo en cuenta las condiciones climáticas del sitio, constitución de los materiales y los antecedentes arqueológicos, que nos permitieron realizar una valoración y cambios sufridos en su constitución física y formal.

Indudablemente, para nuestro caso, la causa principal de deterioro y el principal factor del daño causado en forma directa en las, fue la fragua de cemento, producto del descuido en la ejecución de la construcción del Centro Cultural colindante con el Parque Lítico, que interactuando con agentes ambientales, como la excesiva humectación producto de la lluvia había originado moho, hongos y líquenes en la superficie de las piedras; toda vez que, la excesiva humedad generó disolución y deposición de sales solubles por lo que el bióxido de carbono ambiental somete a los materiales calcáreos al ciclo de disolución y carbonatación superficial que unido a la alta temperatura ambiental, hidrolizaron los componentes de estas piedras. Además, el desgaste producto de la fuerza de las gotas de lluvia, que cae sobre Huaraz en el invierno, el fuerte sol y la fragilidad de la superficie acaban en costras debido a la oquedad en las piedras por arrastre de partículas sueltas. Las rocas suaves, pueden desmoronarse y desprenderse fácilmente al absorber y disiparse el agua por contracción y expansión.

Así mismo, es necesario considerar que este proceso genera grietas, desprendimientos por el efecto físico de arrastre y deposición de sales solubles. La acción de microorganismos también forma parte del deterioro causado por los desechos de aves, puesto al formarse costras se produce una reacción del sustrato con los microorganismos

Todo ello, agregado al cemento adherido a la piedra, al tener un comportamiento diferente al material de las lito esculturas, producirían con el tiempo un daño irreversible. 
La anamnesis, diagnóstico y prognosis determinó, la realización de una limpieza superficial, como proceso de la conservación de este material lítico, adoptando las precauciones necesarias se puso en práctica las operaciones encaminadas a eliminar las causas de los daños producido por el cemento y biodeterioro existente.

\section{El tratamiento de conservación}

Hacemos una descripción sucinta de este proceso técnico aplicado especialmente para este tipo de trabajo que básicamente lo realizamos en dos etapas: la primera consistente en el método del registro y la segunda en el proceso de limpieza.

\section{El Registro}

Una de las primeras acciones para este proceso es elegir el mejor método de registro y reproducción de grabados que nuestro caso se evalúo los siguientes:

Moldados. Proceso por el cual se reproducen a los grabados en forma directa, que se realizaba años atrás, pues era el único de reproducir un tipo de modelado de los petroglifos en 3D. Método criticado pues su intervención directa al ser aplicado para reproducirlo, generalmente producía daño a los grabados, sobre todo cuando los encargados utilizaban productos totalmente agresivos a la parte superficial de la roca en la reproducción de los surcos en el negativo

Frotagge. Se le conoce con este nombre a la acción de friccionar el papel carbón. Encima de otro blanco con el objeto de para reproducir el surco que forma al grabado. De esta manera queda impreso el "negativo" del contenido impregnado en el papel, que no se consideró necesario.

Calco sobre fotografía analógica (Método epigráfico). De lo que podemos inferir es por las características que hemos visto posiblemente la reproducción la realizan calcando las figuras y surcos en forma directa de una foto del grabado, con ello evitan el hacer una transposición del surco grabado a un plástico. Consideramos que no era necesario para nuestro caso.

Calco sobre fotografía digital. Consiste en generar este tipo de representaciones a partir del tratamiento digital de imágenes, que no se usó.

Calco usando estación total. Como su nombre lo indica es un sistema por medio de cual es la estación total la que registra toda la información contenida en las piedras grabadas. Por el costo y por el trabajo específico realizado, fue desechado.

Fotogrametría. Es un método no invasivo, pero sirve muy bien para elementos de gran tamaño pues su reproducción es tres dimensiones, que no se usó.

Registro a través de láser. Esto refiere a realizar un escaneado del petroglifo para obtener su imagen en 3D, Se requiere de un escáner de alta resolución por ser una de los sistemas no invasivos con mejor precisión para reproducir imágenes tridimensionales: No se consideró por su alto costo. 
Fotografía. Técnica muy usada no invasiva con la ventaja de requerir menos tiempo y habilidad, del que adjuntamos una muestra.

Dibujo a escala. Esta técnica es muy importante para poder realizar un análisis interpretativo y compositivo del petroglifo gracias a la subjetividad de sus convenciones que conlleva. Acción que se realizó para este trabajo (figura 01).

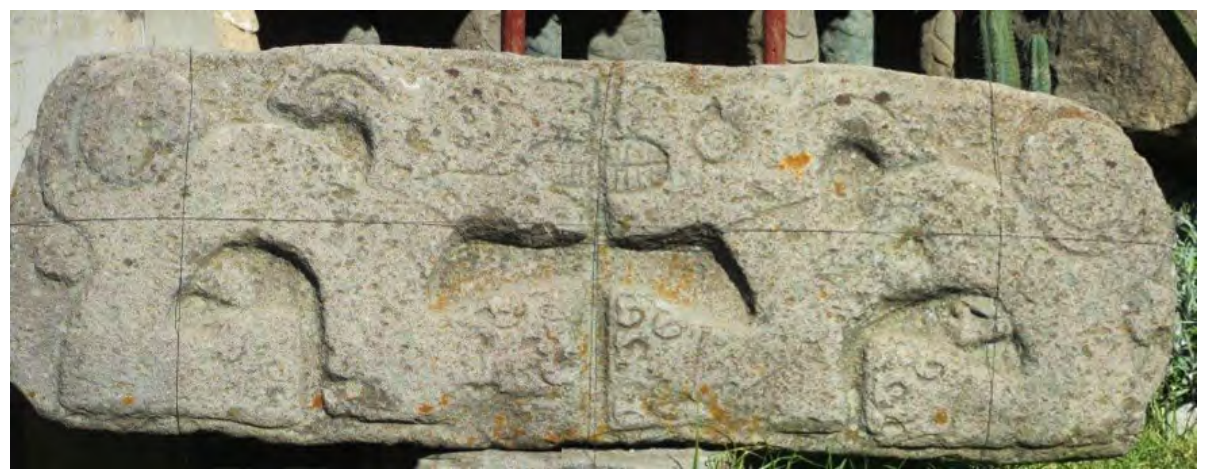

Figura 01. División con dimensiones métricas del original para un mejor control en el dibujo.

Este conocido método, es el requerido y regulado por el Ministerio de Cultura para el registro de toda intervención tanto arqueológica, como para los trabajos de conservación y restauración de monumentos artísticos culturales de la nación.

Nosotros hicimos el dibujo a escala 1 en 10 de cada uno de los elementos previo a su tratamiento y como parte del restauro (figura 02).
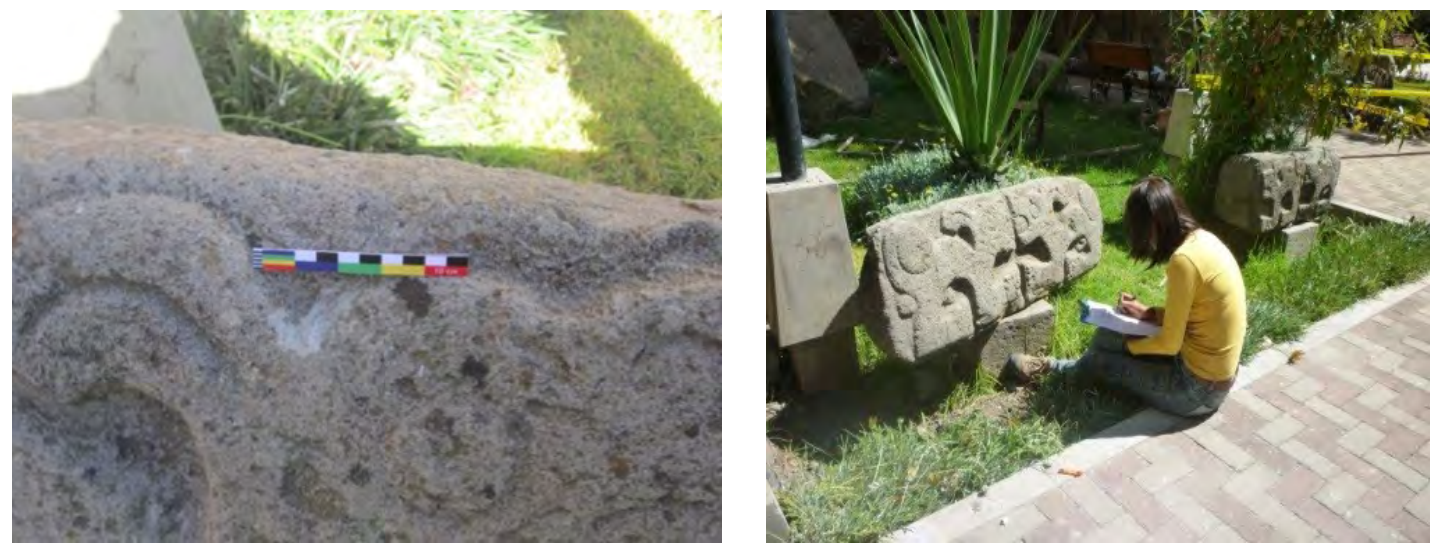

Figura 02. Realización del registro a escala 1 sobre 10 
Calco sobre plástico. El calco en plástico. Esta técnica que es un procedimiento de contacto, consiste en el realizar una superposición manual de las líneas de los grabados, usando algún tipo de rotulador, necesariamente indeleble sobre un plástico flexible y transparente que se coloca en forma fija sobre el petroglifo. Por lo general, en el proceso de calcado también se reproduce las lesiones y contorno de la roca. En este procedimiento se deben considerar dos fases; el que se realiza en el campo en el del gabinete. Es de uso común y muy usado, generalmente combinado con la fotografía

El calco in situo. El primer paso para esta acción es realizar una buena limpieza de la superficie del elemento lítico. Se utilizan distintas condiciones de luz natural o artificial, porque no podemos realizar un calco sobre una superficie que no está exactamente definida, sobre todo si los surcos no son muy profundos; por lo que es necesario realizar previo a ello un buen examen, identificación y delimitando de los motivos grabados. Luego, se coloca el plástico sobre el petroglifo cuidando no afectarlo al tener contacto directo con la superficie. Se va perfilando las figuras poco a poco sobre el plástico, usando los rotuladores tipo indeleble, como diferenciación de colores y/o trazados. Es necesario buscar un equilibrio entre la información que nos será útil y un exceso de registro de la información; no obstante, dependiendo del proyecto tendrá que decidirse la menor o el mayor registro de datos (figura 03).
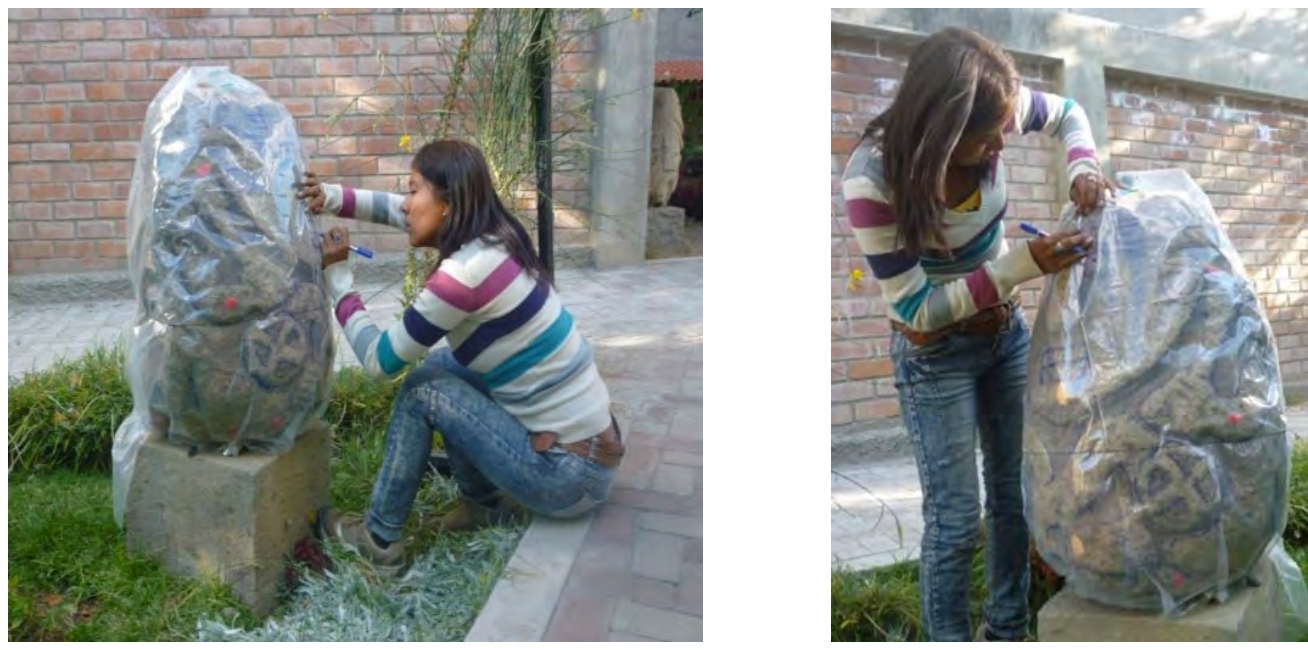

Figura 03. Calco 1 en 1; sobre el plástico para un mejor control del monolito

Trabajo en gabinete. Como segundo paso, como acción previa, se recomienda el traspasar el calco a un determinado formato digital, por lo que se requiere realizara fotografías digitales de todos los plásticos donde se encuentra el registro. Para esto tenemos que fijar las hojas a una superficie blanca vertical apropiadamente acopladas, traslapando las partes de los plásticos, de tal forma que toda la figura coincida 
correctamente para luego traspasarlo a un dibujo a escala, que para nuestro caso lo hicimos 1 sobre 10.

\section{La Limpieza}

Como segunda fase del tratamiento técnico del restauro y como parte de la metodología, se procedió a realizarlo la limpieza del material lítico, con personal especializado.

Sabemos que en el Ministerio de Cultura de nuestro país no cuenta con protocolos de conservación y restauración de bienes inmuebles arqueológicos, menos, para el tratamiento en piedra; por lo que, estos trabajos se realizan siempre según el conocimiento y el expertis del conservador.

El conseguir un total éxito en el tratamiento de conservación de los petroglifos depende de la precisión y de las consideraciones de la limpieza estética, al ser esta una acción necesaria para la conservación de la piedra que se encuentran al aire libre, porque nos permite eliminar de toda la superficie loa productos peligrosos que las afectan, que pueden ser sales solubles o catalizadas, generalmente por la oxidación del dióxido de azufre.

Hay que recordar que el proceso de la limpieza de los petroglifos resulta ser un proceso peligroso; por lo que, en su ejecución deber ser muy cuidadoso, pues producto de un mal procedimiento puede originarse nuevas lesiones, producirse de sales solubles que se alojan en los poros de las piedras, que no se podrán evitar. Situación que en el futuro produciría una nueva degradación incluso mucho más activa (figura 04).
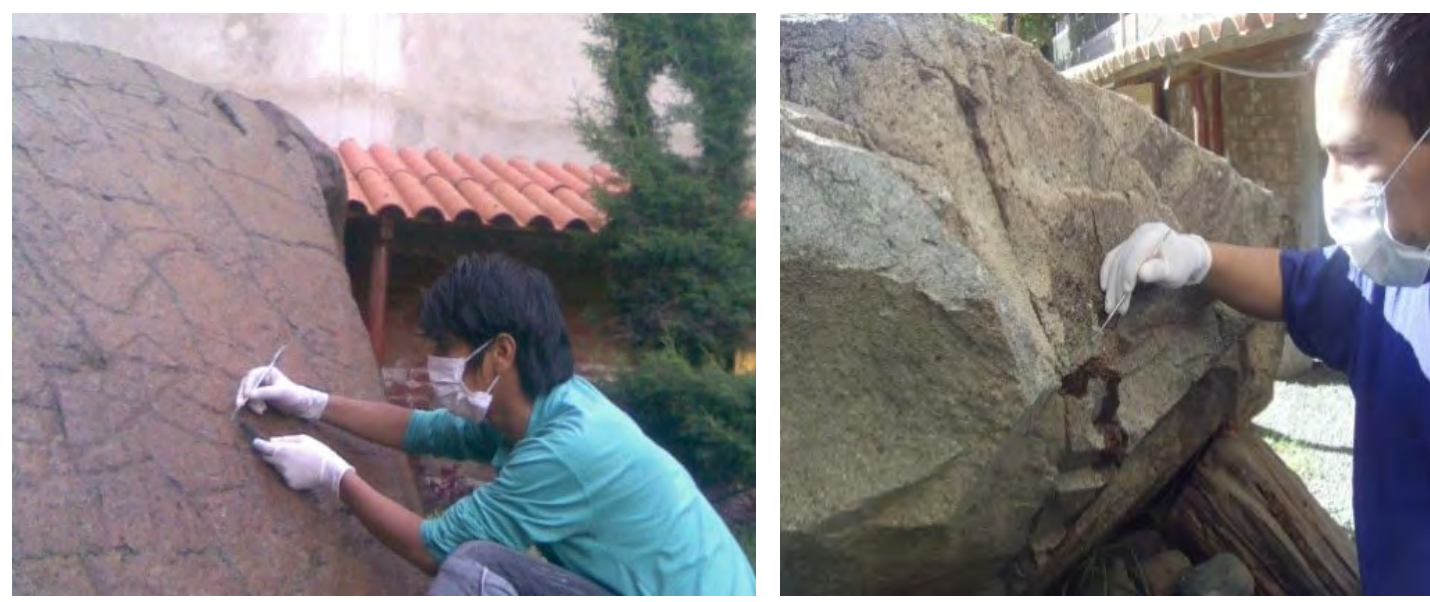

Figura 04. Proceso de limpieza en forma mecánica de líquenes y fragua de cemento se realizó con sumo cuidado 
En el proceso de intervención se incluyen diferentes tratamientos; la ejecución de buscar la solución a cada una de los problemas, dependen indudablemente de las lesiones y estado de conservación del petroglifo. Se recomienda de ser posible, empezar por la limpieza, considerando su estado de deterioro, debe realizando una la limpieza lo menor agresiva posible, y si peligra o puede ser alterada; entonces, mejor sería primero consolidar la superficie dañada.

Los métodos, o procedimientos que nos ofrece la nueva tecnología en la conservación de material arqueológico aseguran un buen resultado, el usar, por ejemplo, agua producto de la niebla de la sierra, agua destilada, "pappettas" generalmente químicas (con un ph igual a 8), cepillos de cerda suave, ultrasonido, etc. Los métodos de limpieza usados por nosotros fueron: al agua, producto químico y acción mecánica.

El objetivo de limpiar una piedra es la de eliminar productos peligrosos, como sales solubles en agua, incrustaciones insolubles, polvo, hollín, micro flora, líquenes, tierra húmeda, algas, vegetación, o cualquier otro agente depositado sobre el material lítico. Se considera siempre, que es fácil la eliminación de las algas como el musgo y más complicado la limpieza de líquenes o como fue este caso del retito total de los restos de fragua de cemento adherido en manchas, en todas las piedras tratadas. Esta fue una operación realizada con extremo cuidado, sin afectar a la superficie de los petroglifos, menos el provocar reacciones negativas sobre los mismos (figura 5).

En el tratamiento, no se permitió la presencia sales solubles, que son peligrosas para la conser-
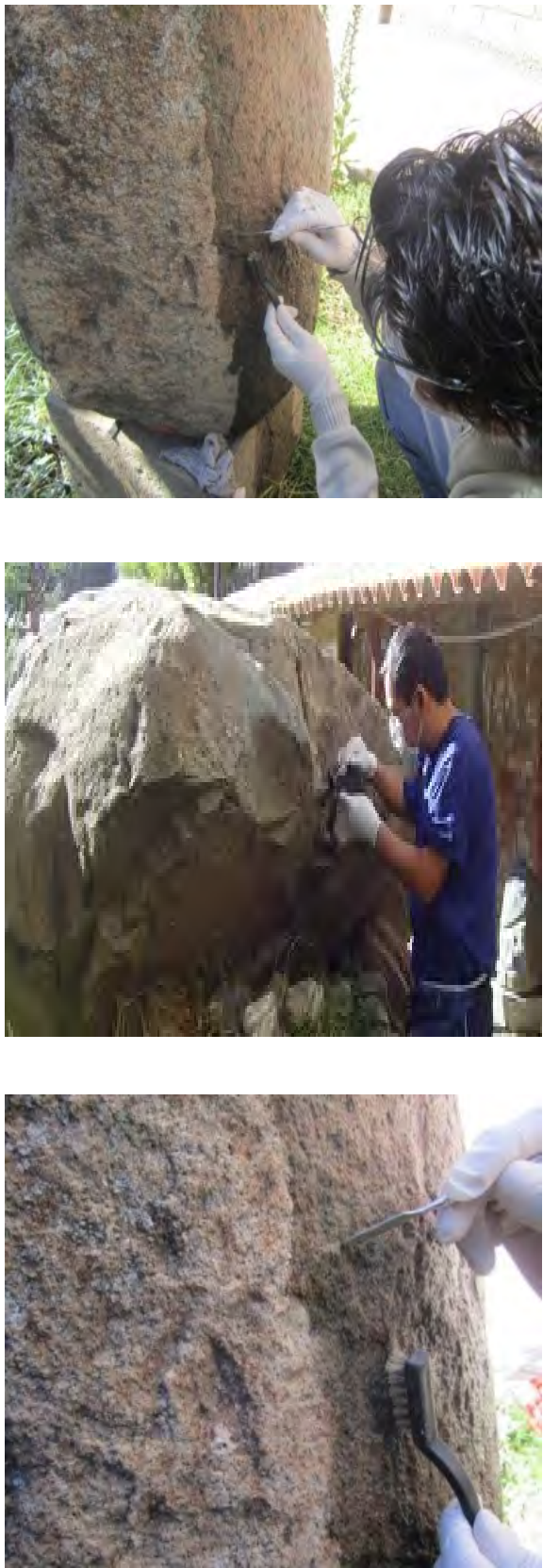

Figura 05. Diferentes vistas del Proceso de limpieza vación de la piedra, por lo que las acciones de limpieza deben realizarse en forma efectiva, eliminando todos los elementos peligrosos depositados en la superficie de los petroglifos realizando un control y evaluación continua de los efectos los productos usados. 
Se tuvo cuidado que el método y la técnica aplicada no cause una fuerte abrasión, micro fisuras, o discontinuidad, pues podía genera un daño mayor, por lo que la acción de la limpieza fue lo suficientemente lenta como para permitir un control por parte del operador.

Se usó instrumentos blandos, como esteques de madera, espátulas de cocina de material plástico, y esponjas suaves y duras que nos sirvieran quitar la capa más gruesa formada por los líquenes y musgo, siendo en la mayoría de los casos suficiente y efectivo.

Posterior a este tipo de limpieza se procedió a realizar un "barrido" de toda la superficie, para lo cual se usó agua y cepillos de cerda suave, eliminando aquellos residuos, sobre todo cuando había mucha suciedad superficial.

Importante fue tener presente el principio del respeto a la "pátina", concepto actual que incluye diferentes acepciones; tales como: "Tonalidad o aspecto externo" que cualquier piedra o elemento adquiere por "envejecimiento", por el tiempo transcurrido, y/o efectos de la intemperie. También puede tener una decoloración producid por causas ya sean naturales o artificiales. La formación de "película coloreada artificial" (patinación). Que viene a ser una película de tipo orgánico (por ejemplo, las producida por algas) cuya tonalidad es versátil (pátina biológica). También puede ser a lo se le llama "teñido superficial" producto de disímiles substancias: (pátina de tinción). Y la más común que es la "acumulación superficial de suciedad" (determinada como pátina de enmugrecimiento). Estas deben ser conservadas por razones históricas, estéticas e incluso técnicas, ya que, en general, desempeña funciones de protección, por lo que sólo se eliminó las materias acumuladas sobre las piedras básicamente los residuos de cemento y bióticos, sin confundir a la mugre con la pátina.

\section{LITO ESCULTURAS INTERVENIDAS}

\section{Dintel $\mathrm{N}^{\circ} 1$}

En esta lito escultura, se procedió siguiendo la metodología explicada eliminando, líquenes, moho, esporas y fragua de cemento.

\section{Registro gráfico y fotográfico (figuras 06 al 10)}
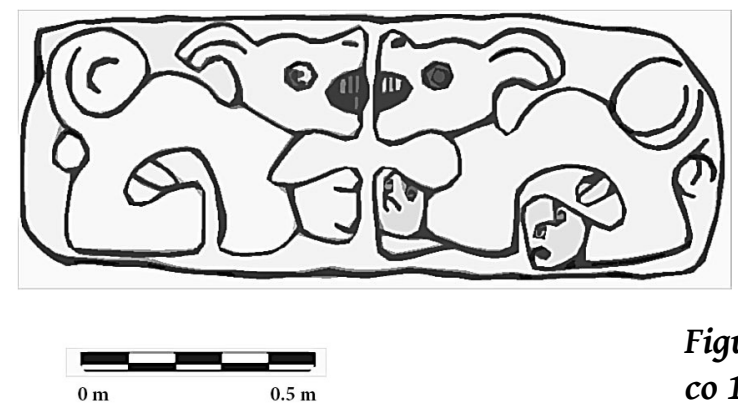

Figura 06. Registro gráfico 1 sobre 10 

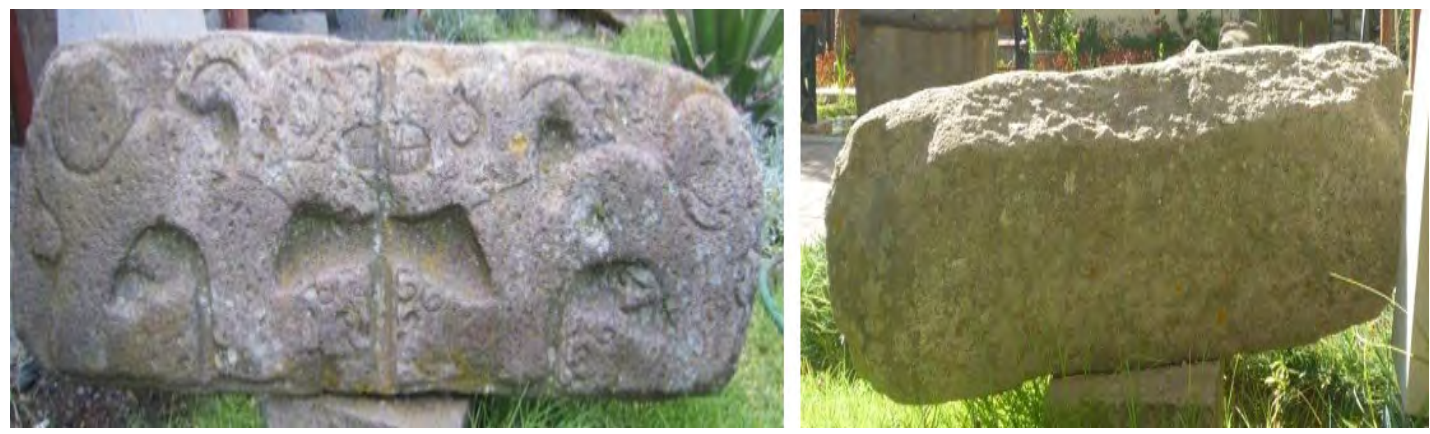

Figura 07. Puntos de cemento adherido al dintel
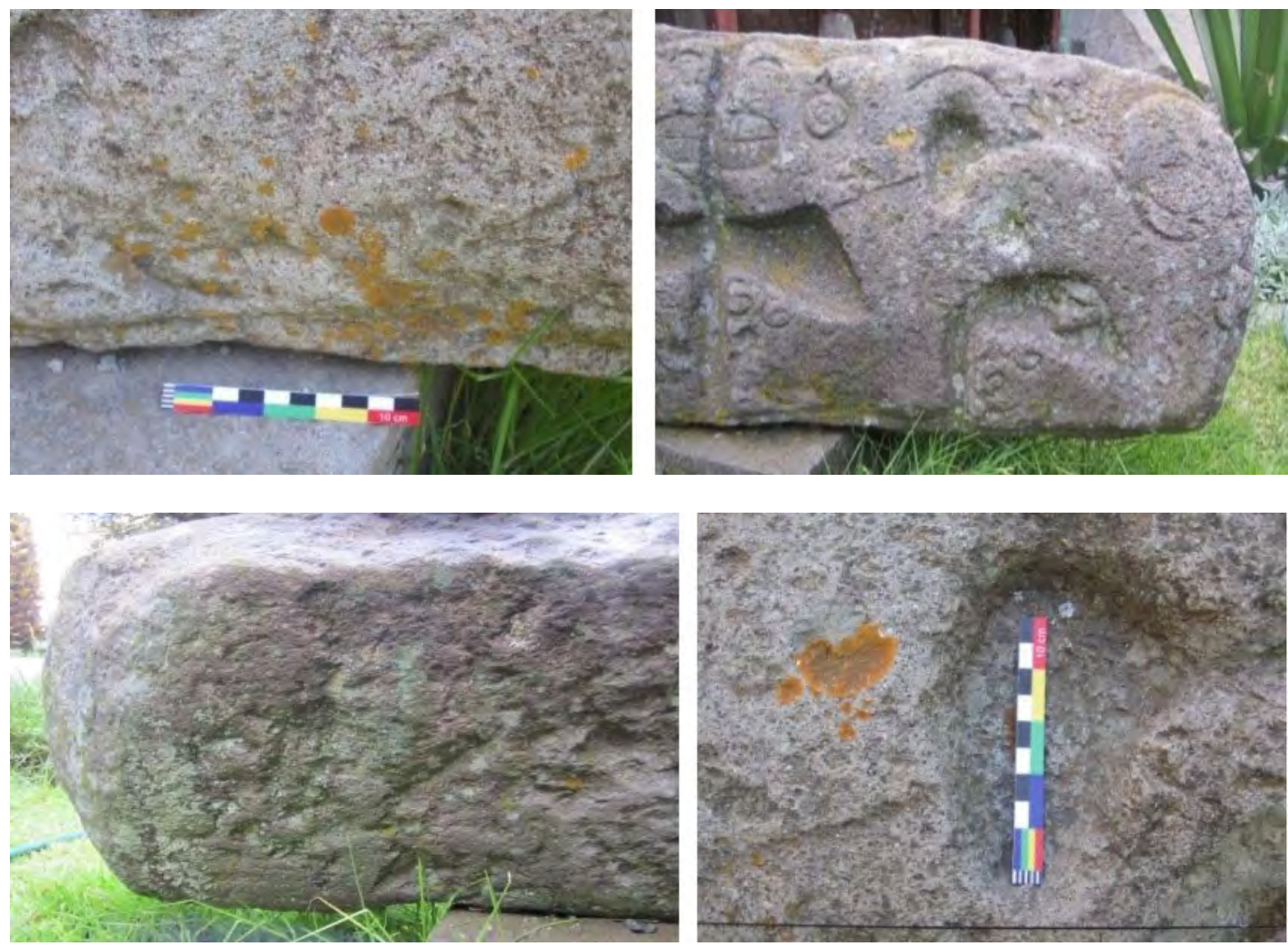

Figura 08. Detalles de líquenes, moho y esporas 

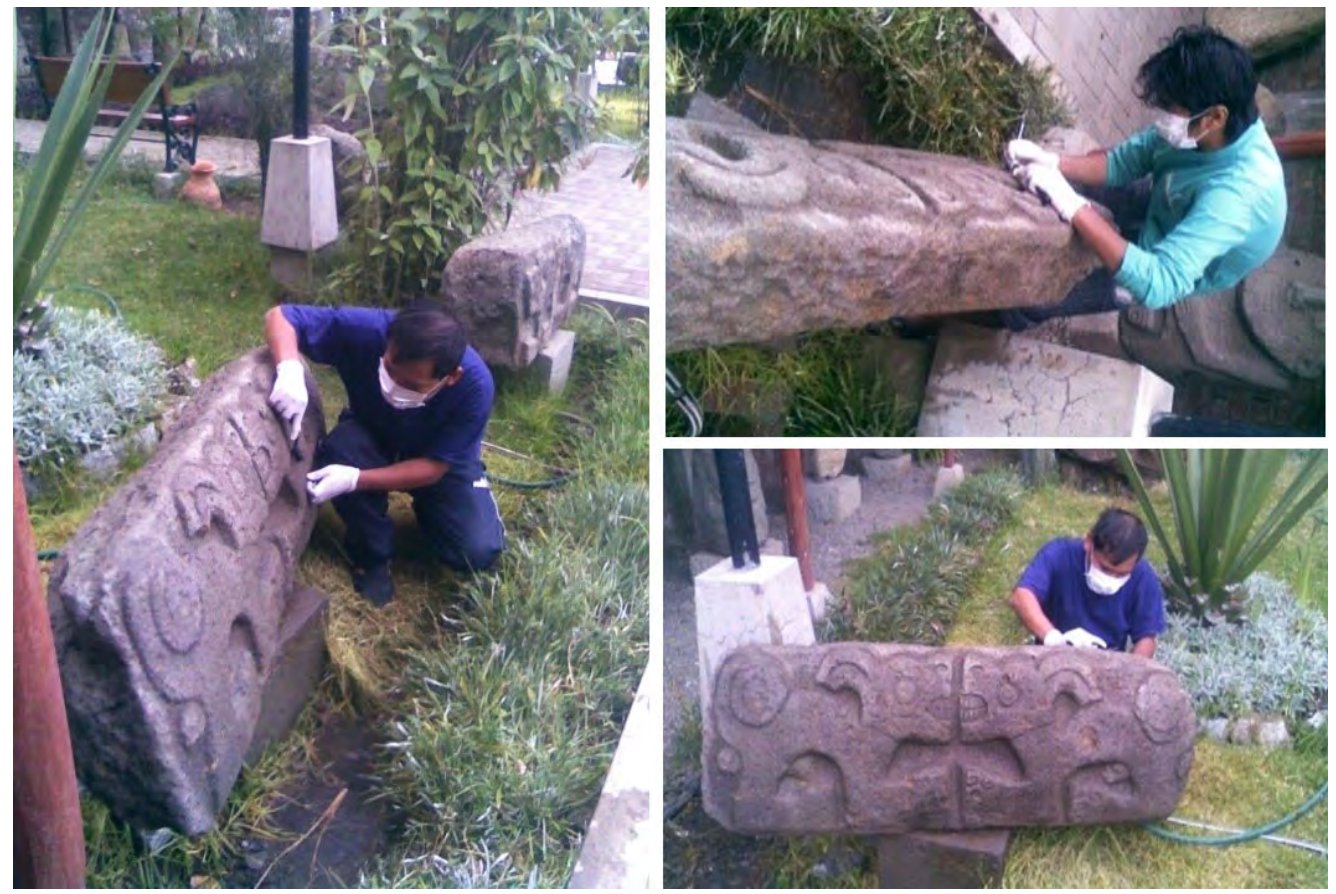

Figura 09. Proceso de limpieza
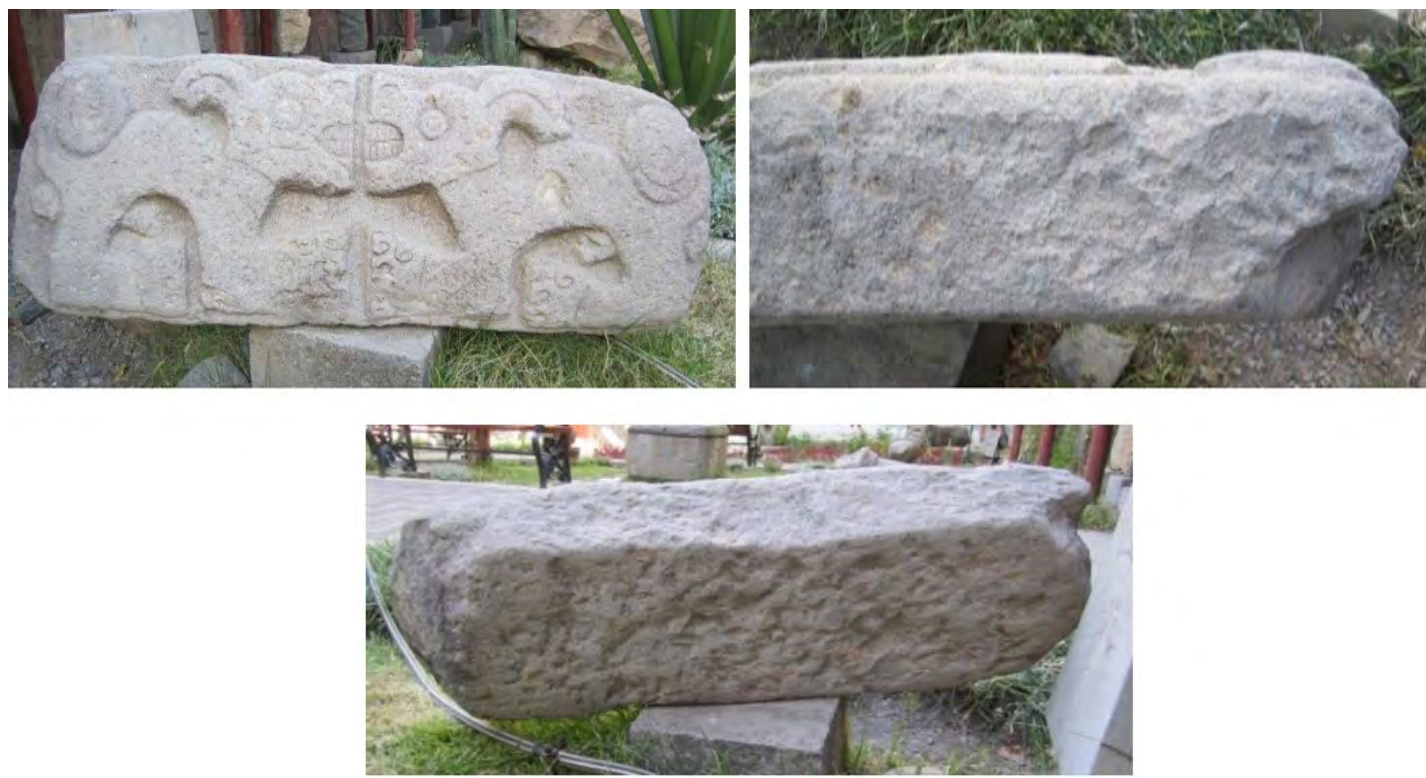

Figura 10. Limpieza completa 


\section{Dintel $\mathrm{N}^{\circ} 2$}

En esta lito escultura, se procedió siguiendo la metodología explicada eliminando, líquenes, moho, esporas y fragua de cemento (figuras 11-15).

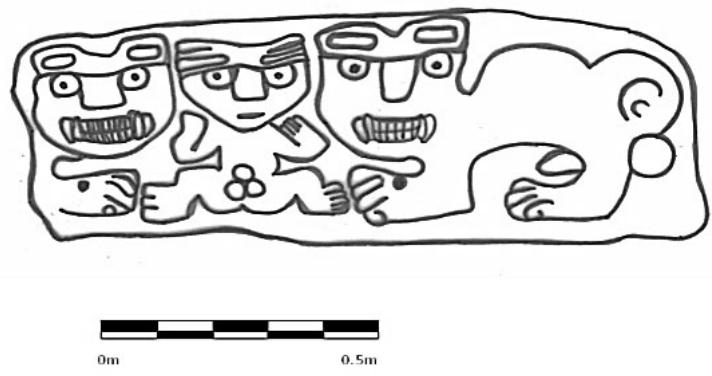

Figura 11. Registro grafico 1 sobre 10
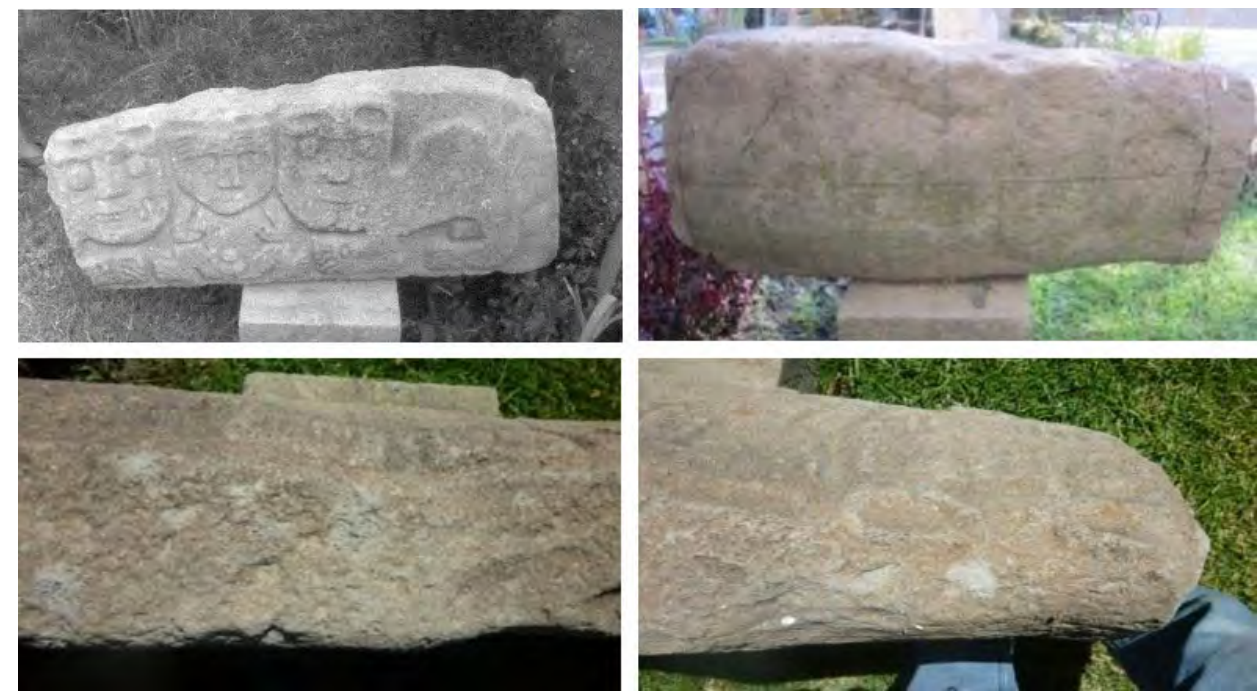

Figura 12. Registro de fragua de cemento

Figura 13. Registro de líquenes, moho y esporas 

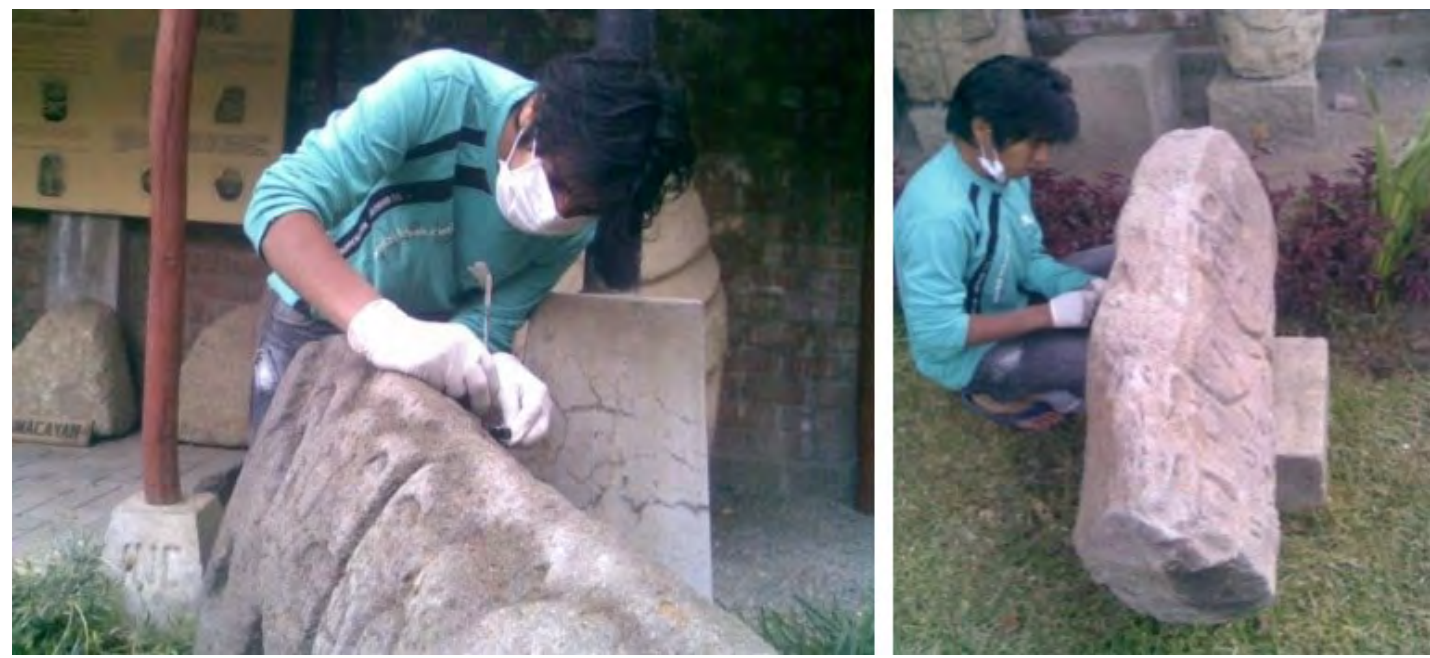

Figura 14. Proceso de limpieza
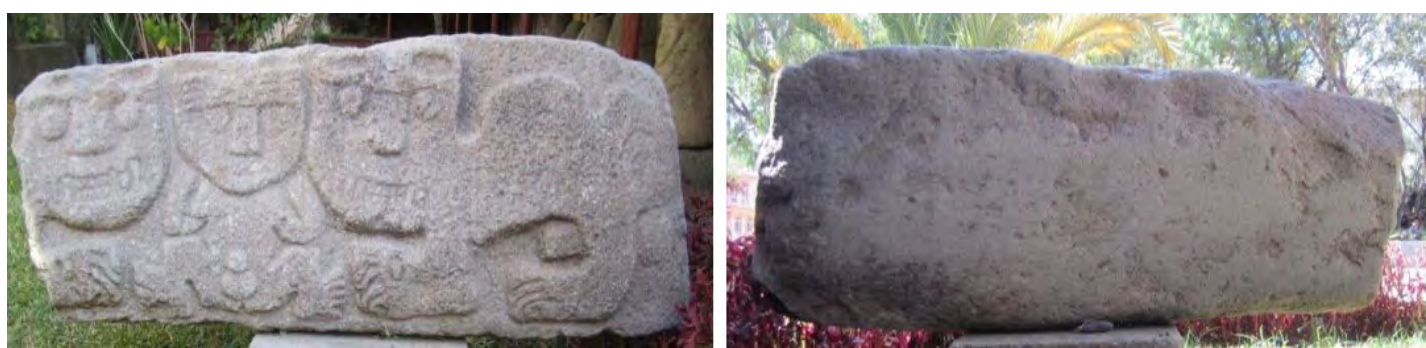

Figura 15. Limpieza terminada

MONOLITO (figuras 16 al 19)

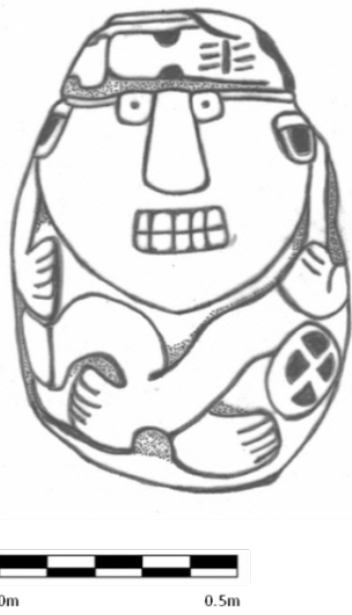

Figura 16. Registro gráfico 

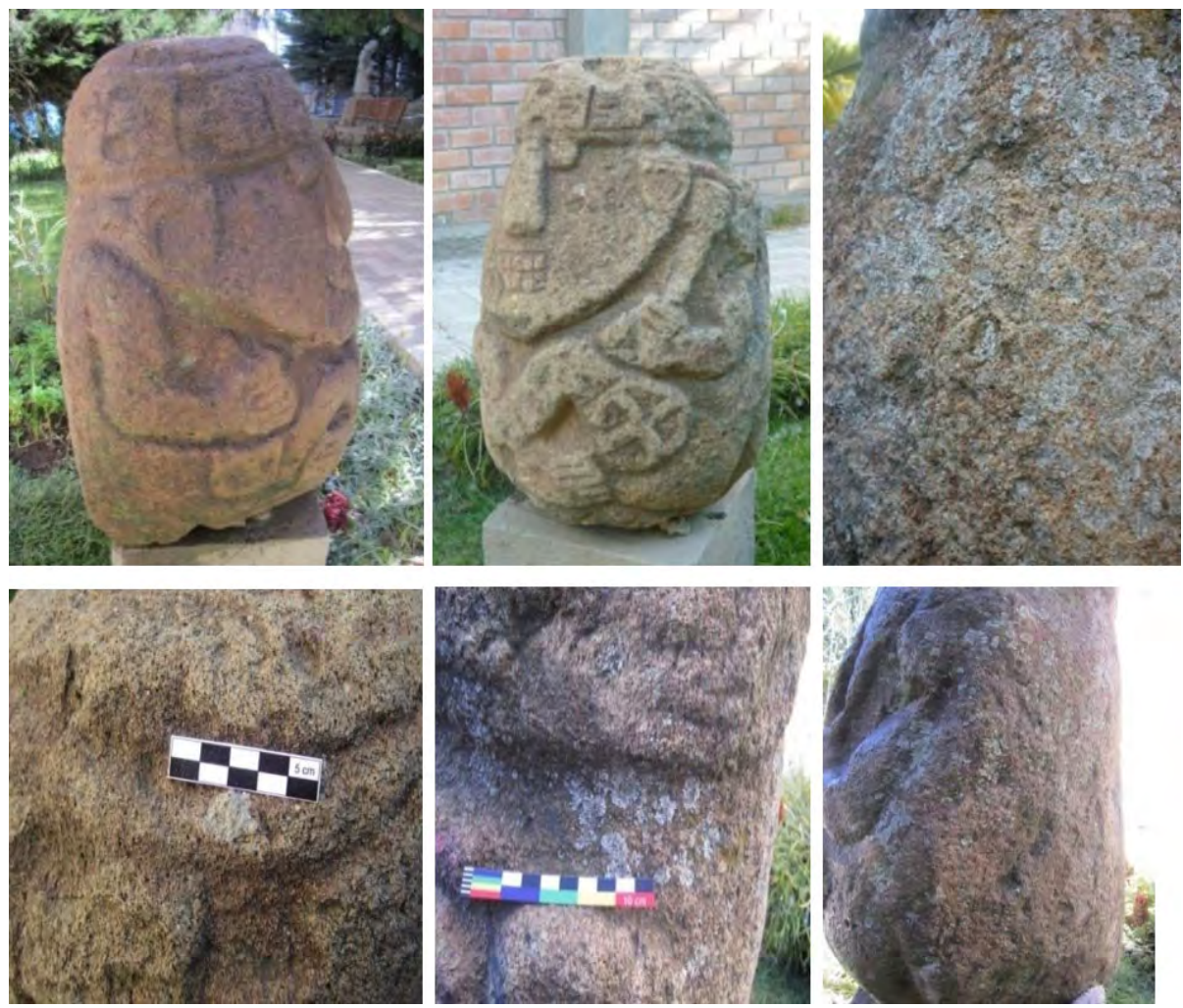

Figura 17. Fragua de cemento líquenes y moho
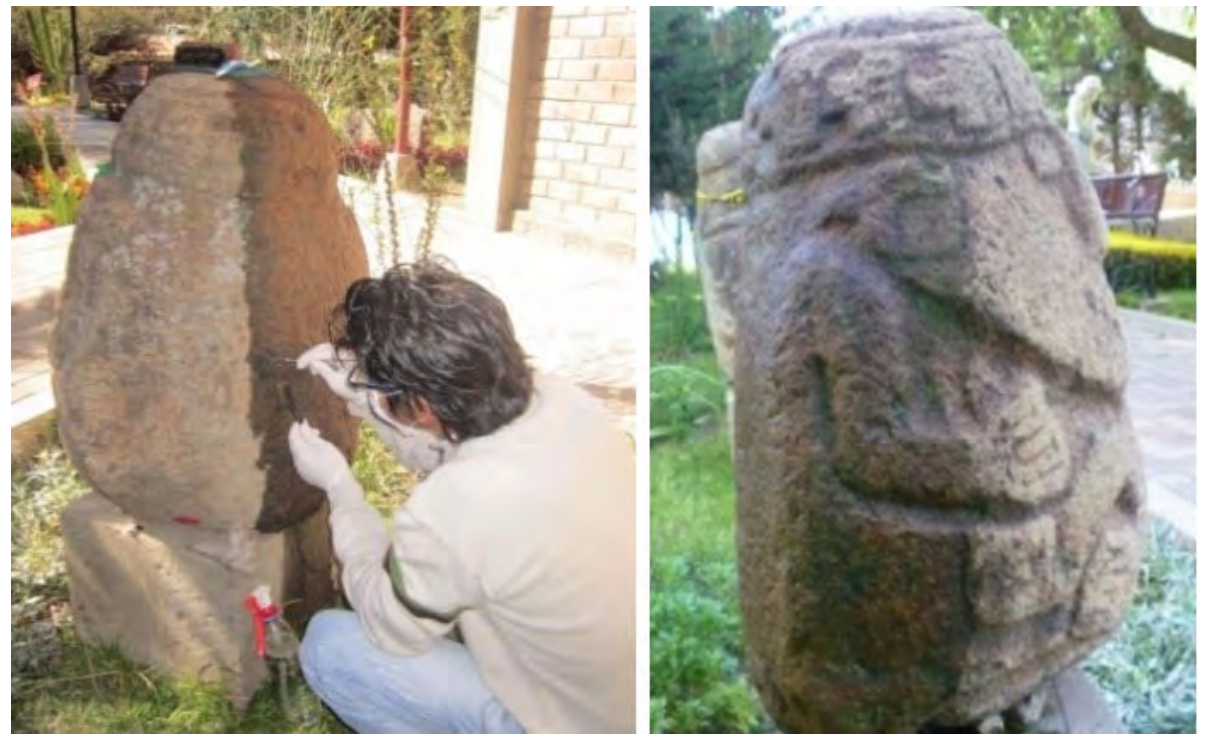

Figura 18. Proceso de limpieza 

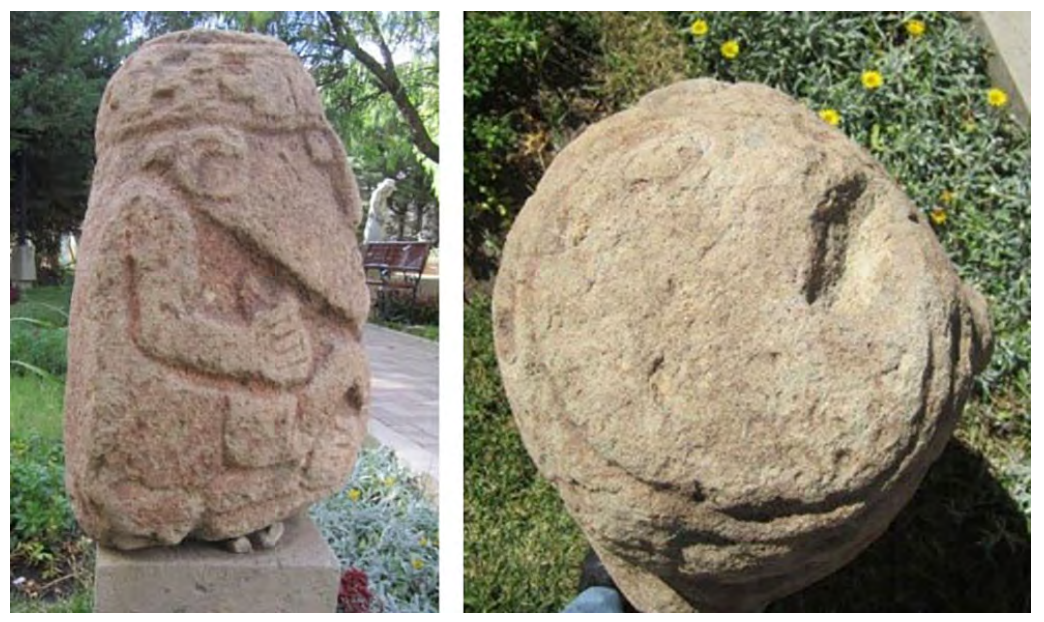

Figura 19. Proceso terminado

\section{EL PETROGLIFO ISABELITA}

Petroglifo del griego "petros: piedra y griphein: grabar"; es decir, son las piedras grabadas con diseños generalmente de imágenes simbólicas que se realizan haciendo incisiones en la capa superficial usando diferentes técnicas como el de percusión, abrasión, rayado, etc. La referencia del petroglifo conservado, fue tomado primero de la publicación de Víctor Ponte titulado "Un análisis del grabado de La Roca Isabelita y su contexto arqueológico, Callejón de Huaylas. Perú. University of Wisconsin, Milwaukee (Ponte Rosallino, 2009); posteriormente fue confrontado con la publicación del mismo autor realizada por la Barrik bajo el título de "Arqueología en la Cordillera Negra del Callejón de Huaylas, Perú: Ârea de Influencia Mina Pierina” (Ponte Rosalino, 2014), donde él mismo dice que es un artículo modificado y traducido del original: "An analysis of the Isabelita Rock Engraving and its Archaeological Context, Callejón de Huaylas, Peru", que se encuentra en la revista "Andean Past 9 (2009):131-175".

De conformidad con las publicaciones del Lic. Ponte (Ponte Rosalino, 2014, pág. 38), "Isabelita es el nombre de una impresionante peña con grabados descubierta en el sitio Amá II (Pan5-49)", correspondiente al Horizonte Temprano del Callejón de Huaylas de Perú que fue descubierto en 1,998, mientras realizaba un estudio Arqueológico alrededor de la Mina de Oro Pierina. La roca estaba de pie, en la parte superior, o barrio Cotojirca, del pueblo de Mareniyoc, en el distrito Jangas, Huaraz, Ancash.

El pueblo moderno de Mareniyoc, está al pie sobre un montículo artificial consistente en deposiciones culturales de 1200 por 800 metros aproximadamente "y consiste en una serie de plataformas escalonadas y áreas habitacionales donde al parecer se llevaron a cabo actividades ceremoniales y domésticas, como es indicado por los gruesos basurales y depósitos que se muestran en los perfiles." (Ibidem, 43) 
A juzgar por artefactos disturbados, por construcciones y remodelaciones, la primera ocupación de Mareniyoc probablemente ocurrió durante el Horizonte Temprano. El actual poblado de Mareniyoc se encuentra sobre un montículo artificial, ocupado varias veces y está asociado a la roca Isabelita, integrado a la puna y zonas temperadas cerca al río Santa, sistema vertical que funcionó por miles de años, de conformidad con el registro de los perfiles del montículo. Siendo Mareniyoc el centro de un territorio con unidad cultural, política, económica, y quizá ideológico solidificado en la simbología religiosa presente en la roca Isabelita (figura 20).

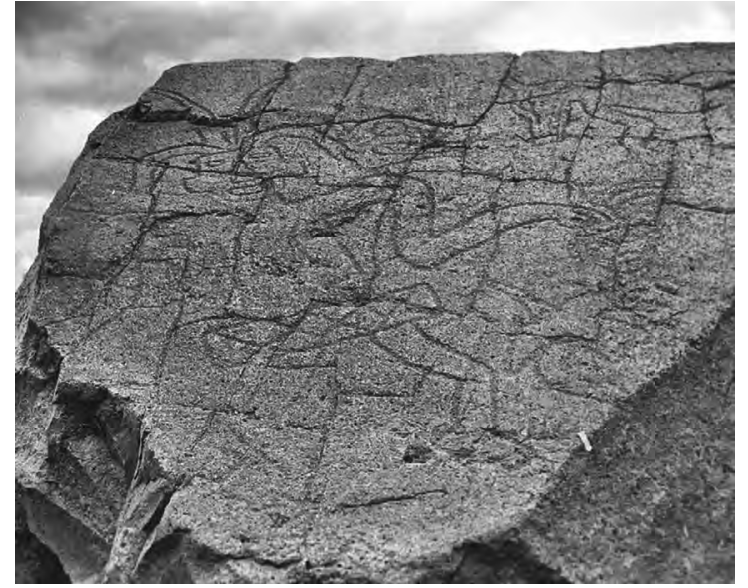

Figura 20. Imagen recuperado de la publicación de Ponte. (Ibídem, 38)

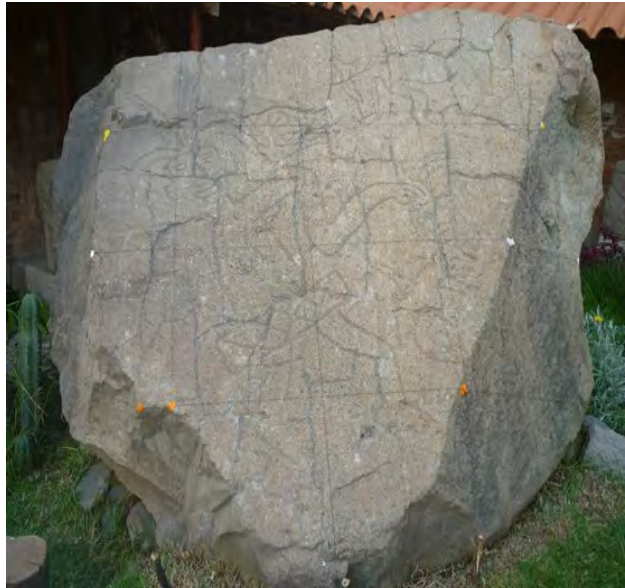

Foto del autor, 2012

Asimismo, en referencia al lugar, espacio, altura arquitectónica, fue el punto central donde tuvieron celebraciones rituales mortuorias que encuentra conectado con una modesta estructura ceremonial de piedra que circunda una gran peña. Un entierro humano con ofrendas se colocó bajo la peña, fue un espacio funerario insertado con piedras rústicas de poca factura constructiva e infiere que:

La gran peña constituye un "machay", un concepto en la lengua Quichua que significa abrigo rocoso natural o una caverna, un lugar donde se realizaba performances rituales. Malqui significa el entierro, la momia del ancestro o fundador de la comunidad local. En base a estos conceptos, se interpreta que la población debió reunirse en una terraza próxima a la gran peña y a la roca Isabelita para realizar veneraciones. En los Andes centrales no se han detectado cultos a los ancestros tan tempranos como el de asociado a la roca Isabelita. (Ibídem, 39)

Amá II, un componente del sitio Mareniyoc, está ubicado en una altitud entre los 3,500 y 3,550 mts., cruzado por una gran cordillera con casas y terrenos agrícolas 
por ambos lados. El lugar tiene una topografía muy irregular y abrupta que incluye grandes rocas usadas en el presente y en el pasado. Las grandes rocas de formas redondas, son formaciones naturales que crean sombras y espacios oscuros. Fue el foco de culto de un barrio, o ayllu establecido en los flancos Este de la Cordillera Negra. La religión y sus rituales son y fueron sumamente importantes para la organización sociopolítica de la comunidad.

Amá, en el actual quechua Ancashino, quiere decir "oscuridad", pero es también un prohibitivo elemento gramatical más o menos equivalente para la palabra "no lo haga". Al respecto dice Ponte (ibidem, 40) que "en este contexto la palabra se refiere a las sombras formadas por las grandes peñas, debido a que la original localización de Isabelita estuvo cerca de cámaras funerarias inmersas bajo largas rocas".

También se puede decir que la fundación Amat II pudo haberse establecido para la realización de rituales funerarios en relación al culto de veneración para los ancestros de este grupo de personas que fue expresada a través de esta roca sagrada, pues en la estructura alrededor de la Isabelita, se encontró estructuras ceremoniales con una tumba denominada por Ponte Amá II E, diciendo que:

La cámara funeraria ubicada debajo de la gran roca tenía por dimensiones: $0.85 \mathrm{~m}$ de alto y $2.15 \mathrm{~m}$ de largo. El espacio fúnebre estaba delimitado por un muro de poca factura pegado a la pared de la roca. El recinto contuvo los restos óseos incompletos de un adulto. El esqueleto se encontraba en posición extendida con la cabeza al sur y los pies hacia el norte. Los huesos estaban malamente preservados debido a la humedad del suelo. Sólo algunos fragmentos del cráneo, fémur y metarsianos se pudieron recuperar. Habían varios ítems asociados al entierro, tales como restos de cuy (Cavia porcellus) puesto en un concha de spondylus, 81 cuentas de crisocola y 136 cuentas de hueso Cerca a los pies la presencia de ceniza pudiera indicar un acto de incineración. Entre las ofrendas cerámicas destacan dos botellas, una jarra y tres cuencos. También se hallaron dos agujas de cobre de $17 \mathrm{~cm}$ de largo. (Ibídem, 54)

Además, por la cerámica encontrada en la excavación, corrobora que el grabado del petroglifo "Isabelita", correspondería al Horizonte Temprano, mientras la estructura redondeada y el entierro a épocas más antiguas (figura 21).

\section{El petroglifo como centro de ritos mágicos religioso}

El lugar donde fue ubicado la roca Isabelita es un espacio donde se realizaron rituales mágicos religiosos y fue asociado a una arquitectura ceremonial donde se incluye a otra gran roca redonda modificada por el hombre. La arquitectura alrededor de la gran piedra y los restos humano debajo de ella, pueden explicarnos de ciertas ceremonias que se relacionaron con el ritual de entierro y la reverencia del "pago" 

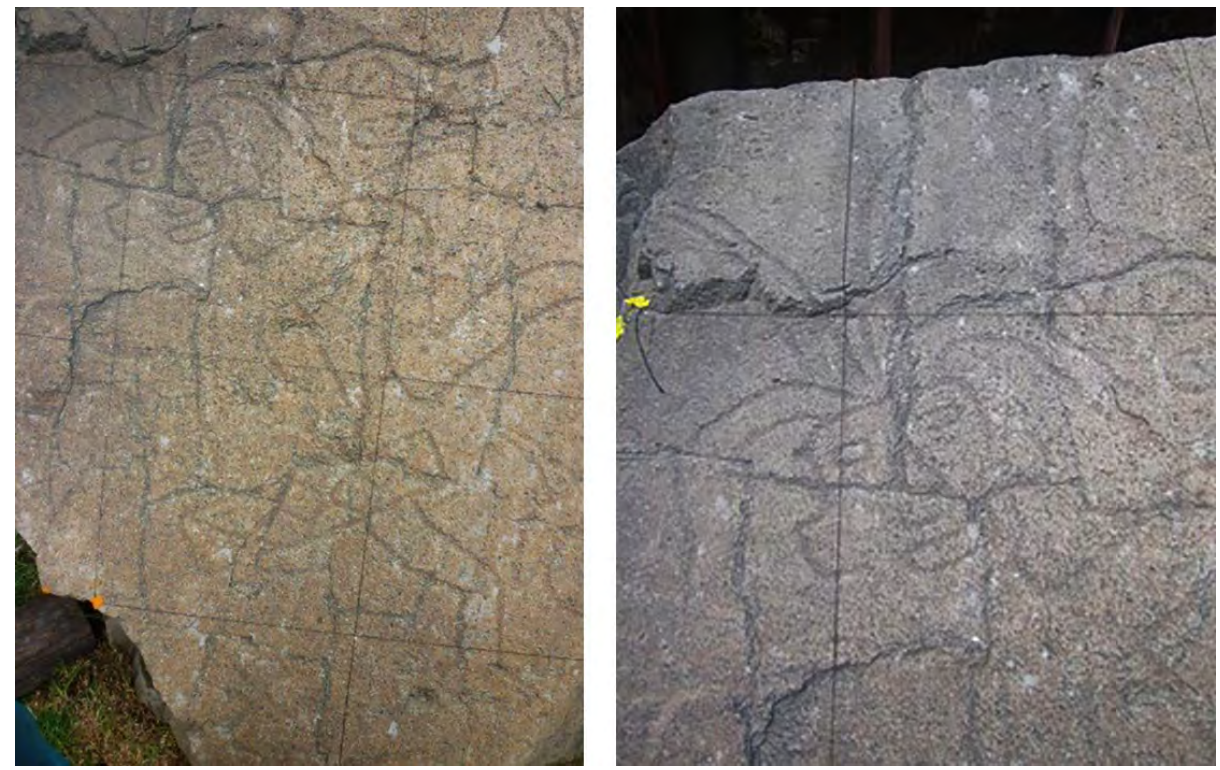

Figura 21. Proceso de evaluación, registro y diagnóstico

del individuo enterrado, pues se encontró con este entierro humano ofrendas bajo esta piedra y dentro de un espacio funerario hecho con piedras del campo.

Otro factor que demuestra el aspecto ceremonial de esta piedra, es su orientación dirigida a lo más alto de la montaña que es la Cordillera Blanca, pues Ponte dice que "en su cavidad interior se observó una aparejo de piedras de forma rectangular alineado al norte, dentro del cual se depositaron restos humanos (...) La orientación de la gran roca da frente a los picos nevados de la Cordillera Blanca, en una línea casi directa con la montaña Huascarán", Esto está relacionado con la conocida costumbre andina de mostrarle reverencia a las montañas a través de ritos realizados con productos del mar". (Ibidem, 52). También reporta que al lado del petroglifo Isabelita se encontró desechos de numerosas ollas.

Es necesario también recordar, que Malqui es el entierro, la momia del ancestro principal del lugar donde las personas pudieron haberse reunido en el espacio terraplenado a la par del montículo Mareniyoc para venerarlo. En los Andes centrales no se ha encontrado ningún culto a los ancestros en cualquier contexto más temprano que el asociado con esta roca Isabelita.

\section{Técnica de ejecución}

El petroglifo se encuentra grabada en una piedra isabelita de tipo andesita que es una roca ígnea con alto contenido de sílice muy común en la Cordillera Negra, tal y como se podía apreciar en el tiempo de la intervención y aún ahora, se pudo 
determinar que fue el resultado de un gran esfuerzo en su factura y un largo periodo de tiempo.

Según una identificación hecha por geólogos de la Mina Pierina y de acuerdo a Ponte (Ibidem, 45), mide 3.0 por 2.5 metros y la roca entera pesa aproximadamente 8 toneladas métricas. Esto fue estimado por la relación de densidad y el peso (según los geólogos) estaba echada con una ligera inclinación formando un plano inclinado. Estaba probablemente en su posición original cuando fue encontrada y estuvo colocada horizontalmente con la cara plana cargando el petroglifo como una mesa. La roca fue amenazada por la construcción de una vía entre Jangas y la Mina Pierina. Por consiguiente, este enorme petroglifo fue trasladado al parque lítico del Museo Arqueológico Regional de Huaraz, donde actualmente se encuentra.

No hemos podido determinar si la ejecución de todo el grabado fue realizado en una sola etapa, de principio a fin, o su producción fue prolongada ya sea por meses en diferentes temporadas o en el transcurso de varios años

No obstante, podemos decir que los grabados en este petroglifo mantienen las mismas características técnicas de la incisión o de ejecución: Por ejemplo, todos los anchos de los surcos mantienen una profundidad de 2 a $4 \mathrm{~mm}$, mantenido una homogeneidad. También que se realizó con un instrumento afilado y duro, por el característico "piqueteado" que se puede notar en el fondo de las líneas al ser percutado para horadar la superficie plana rocosa. Hay pocas superposiciones, y no se reconocen diferencias significativas en el color de la pátina que recubre los diversos surcos grabados. Estas cualidades podrían sugerir que se trató de una actividad continua, donde cada elemento se realizó con base en un ordenamiento consciente.

\section{Iconografía e iconología}

De conformidad con la Enciclopedia Espasa (Espasa-Calpe, 1980, p. 850), iconogra-

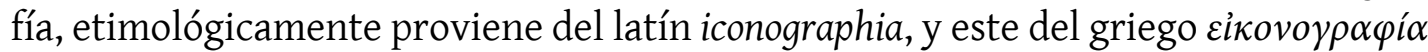
eikonographía, aunque propiamente de las raíces griegas $\varepsilon i k \omega ́ v$ (eikón, imagen) y

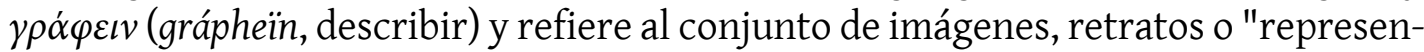
taciones plásticas, especialmente de un mismo tema o con características comunes". Asimismo, la RAE (RAE, 2014), nos dice que es la "representación o imagen de un personaje o de una realidad determinados. Sistema de imágenes simbólicas. Arte de la imagen o la representación plástica". Desde una perspectiva general iconografía refiere "a la descripción y al tratado descriptivo o colección de imágenes artísticas, así como de su simbología y los atributos que identifican a los personajes representados".

Iconología (Ibidem), proviene del griego "eikonología", compuesto de "eikón", imagen y "lógos", tratado y refiere en las Bellas Artes "a la representación de las virtudes, vicios u otras cosas morales o naturales con la figura o apariencia de perso- 
nas". La diferencia conceptual con la iconología, es que, la primera se refiere al génesis y su proceso evolutivo de temáticas figurativas, o mejor a la descripción que ser representas en las expresiones plásticas, mientras que la segunda busca el descifrar cuál es el significado que la contiene

La iconografía es la rama de la historia del arte que se ocupa del asunto o significación de las obras de arte, en contraposición a su forma y según Panofsky (Panofsky, 1985):

[...] el método iconográfico, entendido como el estudio sistemático de las imágenes, tiene por objeto interpretar el contenido temático y el significado de las obras de arte. Un primer nivel de interpretación, la descripción pre-iconográfica, implica la identificación de los motivos reconocidos a simple vista; en el segundo nivel, iconográfico, se reconocen los temas o conceptos expresados, las formas como imágenes; y en el tercer y último nivel, el iconológico, se encontraría el significado intrínseco de la obra, su calidad como síntoma cultural de un momento histórico determinado, representado en valores "simbólicos". (pp. 45-47).

Ahora, para la aplicación de la iconografía en el campo arqueológico devendría en el estudio de toda representación simbólica, estética y de elementos que pudieran contener de alguna forma un significante ideológico-religioso-ceremonial, por lo que cuando analizamos el arte plasmado en elementos rupestres el análisis debe principalmente identificar las escenas, los personajes, los objetos, etc., que se encuentran impresas en el elemento lítico. Por lo que, consideramos importante lo que expresa Martínez (Martínez Celis, 2018), cuando dice que:

Mayor parte de los corpus de arte rupestre, resultan ser del tipo "abstracto"; es decir, que no es posible su identificación directa; esto ha generado una gran cantidad de términos que pretenden definir su "parecido con" algún objeto reconocible: antropomorfo, zoomorfo, fitomorfo, tectiforme, claviforme, astromorfo, etc, etc. En otros casos, cuando ni siquiera es posible especular una equivalencia, simplemente se definen con sus componentes geométricos: círculos concéntricos, rombos, zig-zags, meandros, etc, etc.

Si bien es cierto el enfoque de nuestro trabajo es el de conservación, con el fin de demostrar su valor estético, gráfico y plástico, necesario para su comparación hacemos una breve descripción del contenido del Petroglifo denominado "Isabelita". Y, con el objeto de determinar no solo la parte iconográfica e iconológica de esta representación, sino mostrar los niveles de degradación, consignamos la documentación original y los registros realizado al momento de su tratamiento curativo.

Al respecto, haciendo una comparación artística estilística y marcando distancia nos dice Ponte (ibídem, 65), que existe una diferencia entre la representación de la Piedra Isabelita y la de Sechín en referencia a la posición frontal del personal central 
que coge una cabeza trofeo que no aparecen en Sechín. Por lo que el ejecutor del grabado en la Isabelita pudo haber mantenido la misma técnica, pero se diferencia del contexto cultural al de Sechín.

Esta, es la representación o diseño grabado de una figura completa de un individuo mirando al frente con cuatro apéndices en la cabeza (dos al centro, dirigidas hacia arriba y dos hacia los laterales). Su pectoral es esquemáticamente rectangular y lleva como cinturón figuras geométricas rectangulares encajonadas en líneas que se entrecruzan. Se encuentra en actitud de danzar, debido a que tiene las rodillas flexionadas y con su mano izquierda coge el cabello de una cabeza- trofeo. Adjunto y a la derecha del espectador, se muestran los perfiles de cuatro animales. Junto a su hombro izquierdo la cabeza de un reptil, posiblemente sierpe; en el ángulo superior izquierdo la figura de un zorro o ciervo y en la parte inferior junto a su pierna izquierda un ave unida al cuerpo de una serpiente curvada. Su pie izquierdo está dirigido al frente. En la actualidad ha perdido la huella evidente del derecho, pero por el registro de cuando fue encontraba, este último se encontraba hacia otro lado, lo que significaría que se encuentra en acción o en algún movimiento dancístico.

A través del tiempo (1998-2012), como se puede notar entre el registro que publica en su informe el arqueólogo Ponte y el realizado por nosotros podemos notar una irremediable perdida de los rastros de las líneas, esto, producto de una degradación y falta de conservación de tan importante obra de arte (figura 22).

Haciendo una lectura en su contexto cultural, la figura principal del hombre danzante que lleva una cabeza trofeo acompañado por animales, constituye un dato importante para entender la religión y rituales que se relacionaron con seres y leyendas mitológicas que se perdieron durante la última etapa del Horizonte Temprano.

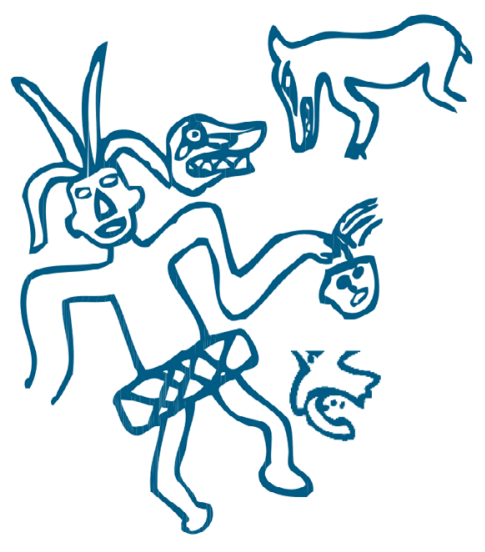

Figura 22. Imagen recuperado de Ponte. (Ibídem, 48)

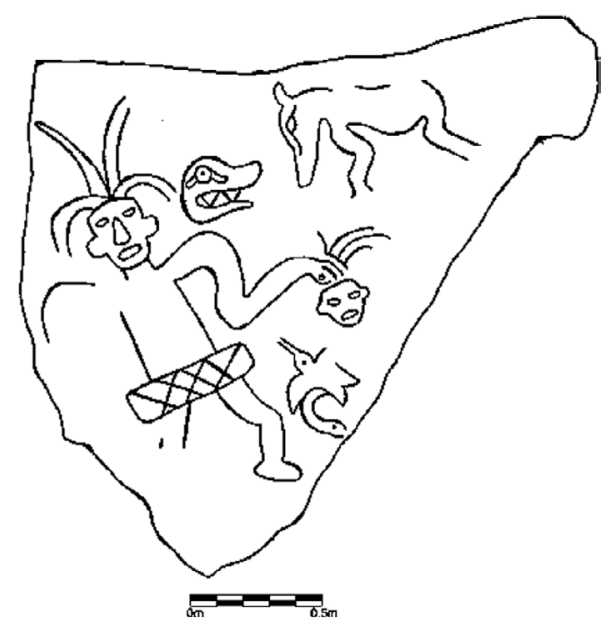

Dibujo 2012. Escala: 1/10 
Si bien es cierto, la figura principal es la representación del jefe, sacerdote, chaman o danzante, al no encontrarse en la parte central de toda la escena no compartimos la idea que sea una deidad. Más bien creemos que el mensaje que transmite esta imagen, representa la escena de un ritual de sacrificio humano, como acción de "pago" a los dioses (figura 23).

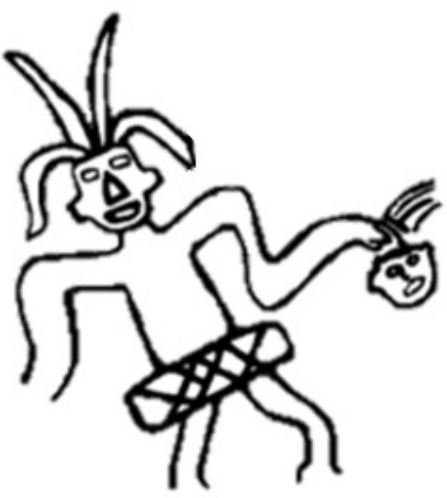

Figura 23. Imagen recuperado de Ponte (ibídem, 52)

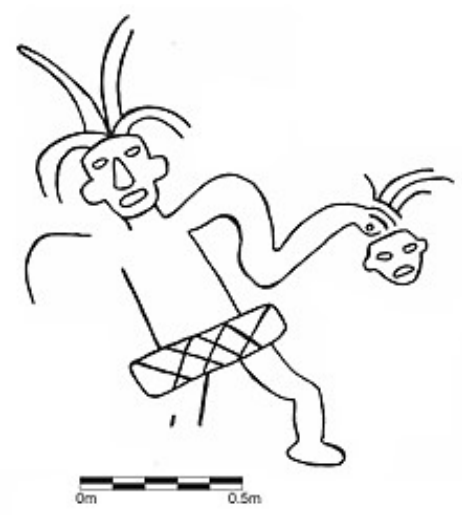

Dibujo 2012

Como podemos notar, se han perdido las partes finales o las puntas de tres apéndices, las líneas del brazo y parte de la pierna del lado derecho que en proyección a la proporción de su brazo izquierdo, que posiblemente también era alargado.

Con respecto a la representación de la cara del hombre, nos describe Ponte (ídem), que "El hombre grabado tiene ojos rectangulares, nariz triangular y boca abierta. Las orejas rectangulares son similares a las mostradas en el estilo escultórico de Sechín." Nosotros creemos que, por la forma que nos presenta los ojos, nariz, boca y orejas, sería la representación de una máscara, acorde con la acción de la ceremonia y la danza en su vinculación con el mundo que lo rodea, vinculado con lo animal y espiritual (figura 24).

\section{Cabeza de la representación del personaje}
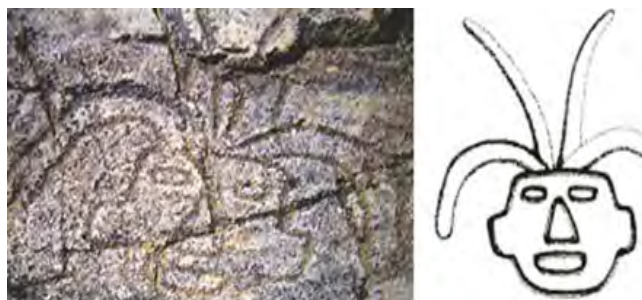

Figura 24. Recuperado de Ponte (Ibídem, 49 y 52)
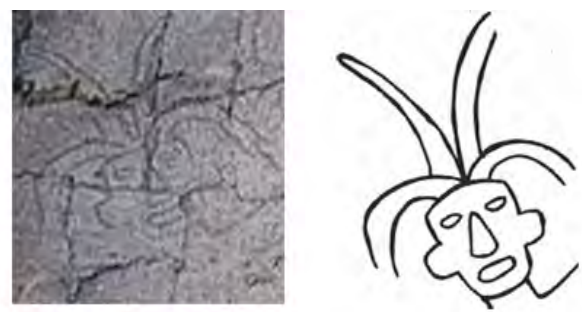

Dibujo 2012 
El brazo izquierdo de la figura humana es exageradamente largo, y sólo se muestran tres dedos que sujetan a su trofeo principal por los pelos que está representado por cuatro incisiones ovoides. La cabeza del trofeo es circular con ojos redondos; diferencia con los del danzante, lo que refuerza estos son la representación real, mientras que la del danzante es la que representa a una máscara (figura 25).

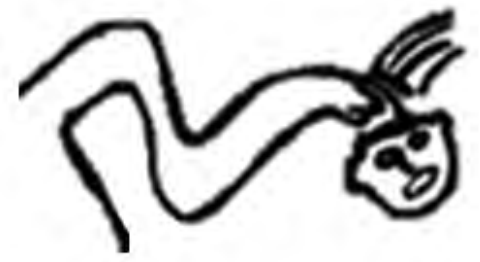

Figura 25. Ponte (ibídem, 52)

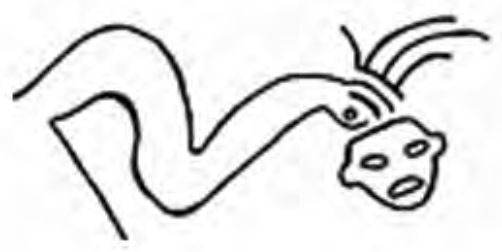

Dibujo 2012

El brazo derecho es menos visible por las fracturas naturales de la roca y por su forma redonda y plana que presenta escalones en la superficie en la cual ha sido esculpido en el lado derecho.

El perfil de un reptil o cabeza de la serpiente está por encima del hombro izquierdo del danzante. Ponte (Ibidem, 49) lo describe diciendo que "tiene un ojo redondo con la pupila remarcada por un punteado inciso. Dos bandas ovoides que se extienden de cada esquina de la conjuntiva podrían representar lagrimones." Muestra dientes aserrados,que en el dibujo de Ponte son tres pero, nostrosos registramos solo dos de ellos (figura 26)

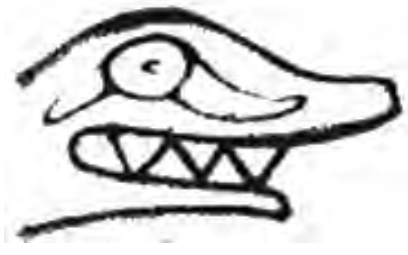

Figura 26. Ponte (Ídem)

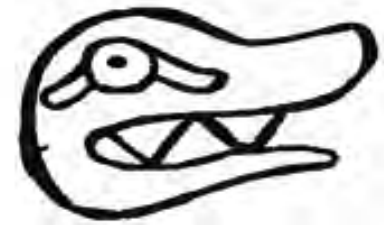

Dibujo 2012. Escala: 1/10

Un segundo animal está en la parte superior derecha es un mamífero representado de cuerpo entero bosquejado completamente de perfil (figura 27).

Esto podría representar a un venado o un zorro con piernas angulares en movimiento, un largo hocico y oreja. Su boca está abierta, mostrando dos dientes aserrados menos visibles que los del reptil. Hay que recordar que en los andes, el zorro está asociado a la productividad y ciclos agrícolas. En la actualidad ha perdido parte de las líneas de su contorno. 

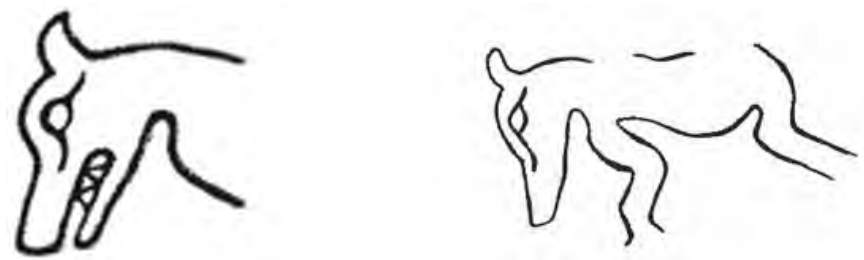

Figura 27. Dibujo 2012. Escala: 1/10

Un tercer animal es un ave con alas extendidas y un largo pico y que actualmente ha perdido la huella de su ala derecha (figura 28).

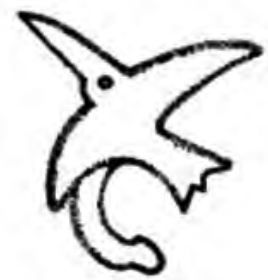

Figura 28. Ponte (Ídem)

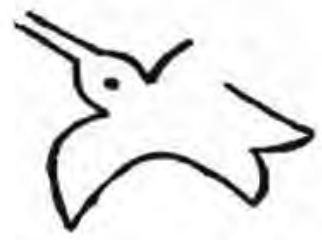

Dibujo 2012. Escala: 1/10

El cuarto animal según Ponte (ídem) es una culebra simplificada que aparece en el fondo la esquina inferior derecha del espectador, debajo del pájaro. La serpiente ha sido trazada de perfil con una cabeza triangular y cuerpo curvado. Esta actualmente se encuentra borrosa (figura 29).

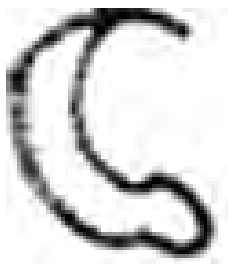

Figura 29. Ponte (Ídem)

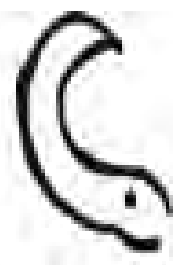

Dibujo 2012. Escala: 1/10

Sintetizando la interpretación, citando a Rowe, a Von Hagen y Morris; Ponte (Ibidem, 65), nos explica que existe una relación y conexión entre la iconografía del petroglifo Isabelita y la manipulación del poder religioso en las estructuras sociales, pues la representación de las imágenes de la boca del jaguar del reptil, el felino, y el ritual religioso que se asocia a seres mitológicos importantes, por lo que sin duda, debe de haber existido una especie de ritual generalizado en los andes cuando la cultura Chavín se encontraba en pleno poder, y los aspectos de este ritual parecen haber sido expresados por el petroglifo Isabelita. 


\section{REGISTRO}

Registro fotográfico (figuras 30-32)

Fragua de cemento líquenes y moho
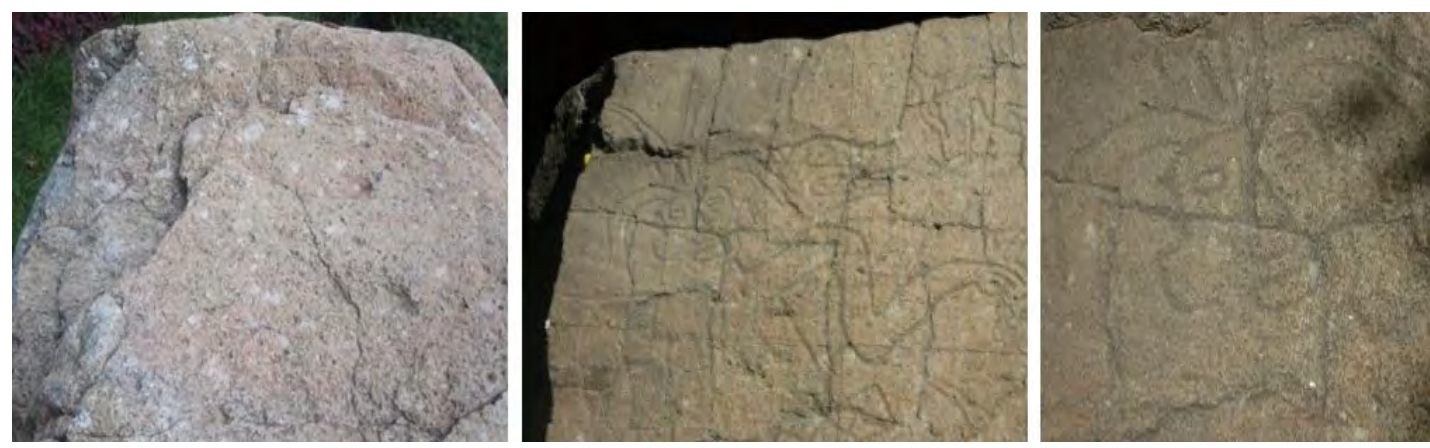

Figura 30

Proceso de limpieza
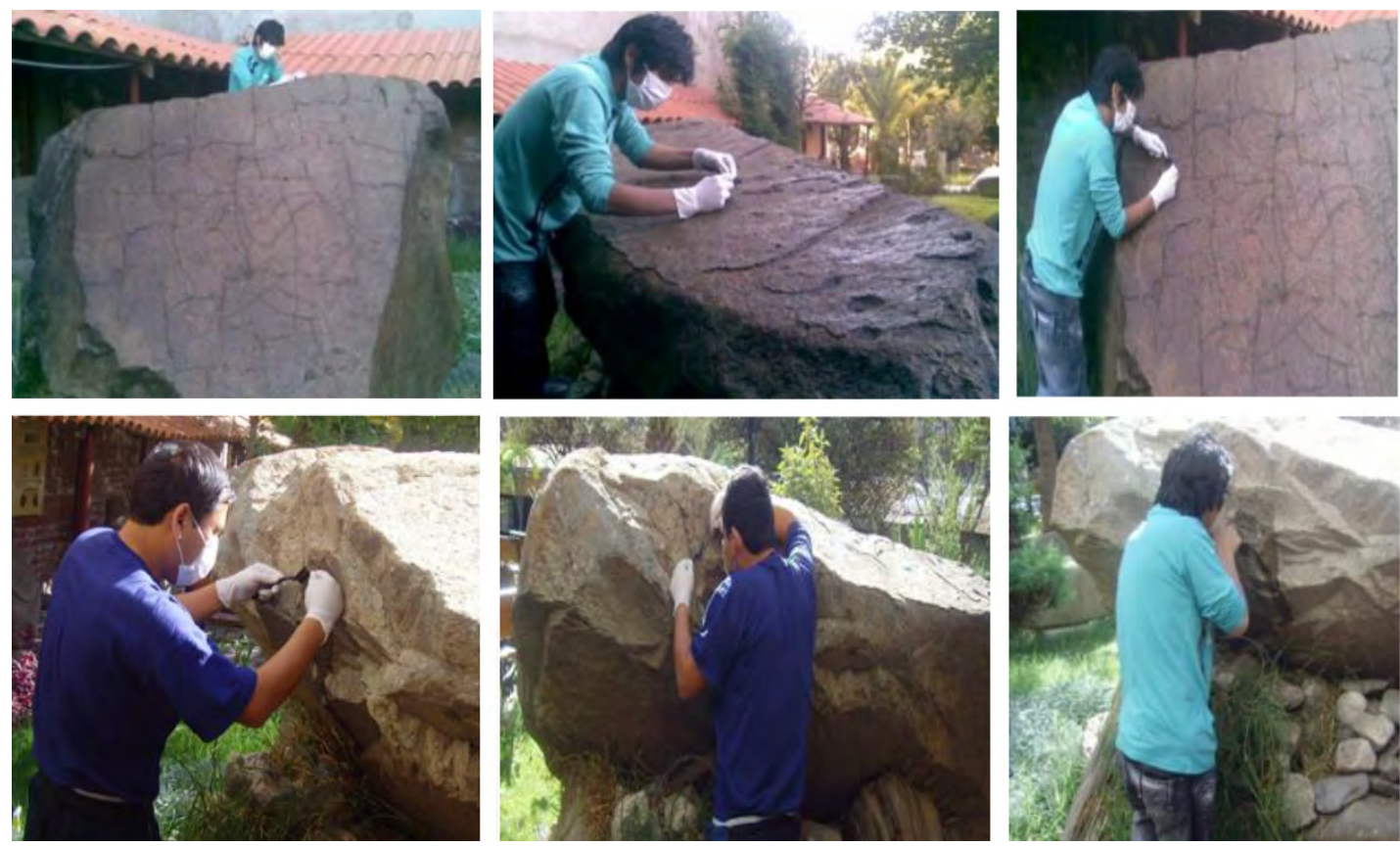

Figura 31 


\section{Proceso de conservación concluido}
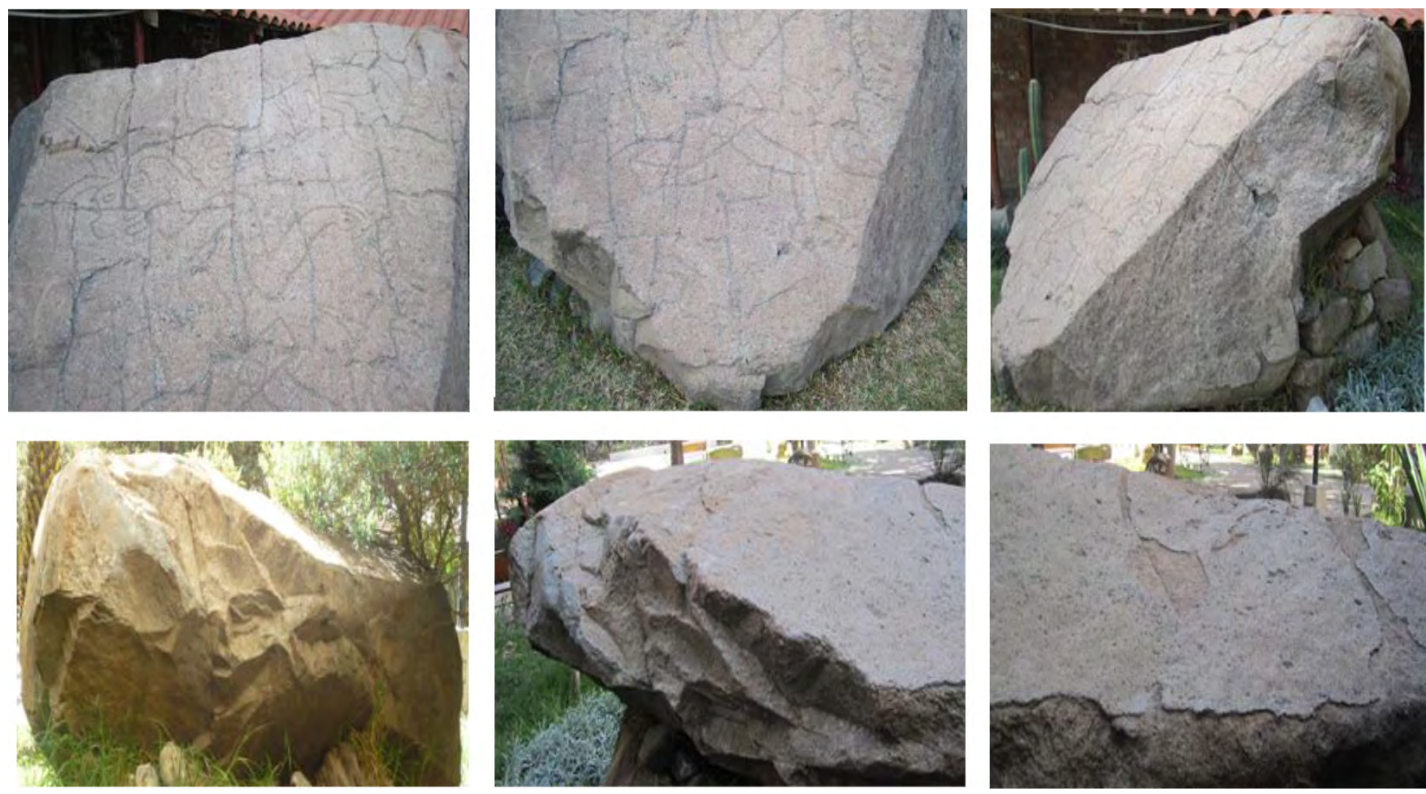

Figura 32

\section{RECOMENDACIONES}

Visto que, las lito esculturas del parque lítico del museo de huaraz, mantienen desde tiempos atrás, una meteorización en proceso gradual de meteorización, con el objeto de realizar acciones de prevención de síntomas y en una prognosis de deterioro, para el resto de los petroglifos expuestos, se sugiere lo siguiente:

a) Realizar un inventario de todos lito esculturas con su correspondiente ficha clínica por cada lito escultura, donde se integre, mínimamente la anamnesis, el diagnóstico y la prognosis, con el objeto de determinar su tratamiento y monitoreo de lesiones y de ser posible la conservación de cada una de estas obras de arte.

b) Impedir circulación de cualquier tipo de agua por las líneas grabadas, pues la causa o generación del deterioro es la humedad, evitando así, la formación de eflorescencias y su penetración por ascenso de capilaridad, condensación y filtración que erosionan constantemente a las rocas. para ello, sería necesario ponerles cubiertas, de tal forma que la superficie siempre se mantenga seca, sin crearles microclimas. Además, ayudaría a que los rayos del sol no incidan directamente en la superficie, y que los cambios violentos de temperatura no aceleren el desgate y el agrietamiento de las piedras.

c) Un proceso de limpiar y recuperar estos bienes arqueológicos plantearía el realizar una desinfección química, de ser necesario, retirando las pátinas agresi- 
vas o suciedad de los desechos de aves, lo que podría eliminarse en forma mecánica o química.

D) Eliminar los agentes biológicos, que son los organismos que viven sobre la superficie, ya que todas las lito escultura del parque lítico de huaraz, tienen incrustado en diferentes áreas, líquenes, helechos y casi en toros mugos, por lo que se hace necesario realizar una limpieza de mantenimiento en las superficies afectadas.

e) En una inspección general, se aprecia que todos los elementos líticos, salvo las silíceas, tienen gran porosidad superficial, y como consecuencia se observa una alteración del color original. Por lo que se hace necesario disminuir la erosión mecánica y por lo tanto, cerrar las áreas fracturadas, sellar grietas y poros, evitando el rompimiento o desprendimiento de fragmentos de la superficie, pues los microorganismos producen adhesión a nivel molecular por atracción electrostática. Estos deben ser tratado con productos nuevos químicos que disocien esta relación o acortar en lo posible su porosidad.

f) Debe de sellarse los poros para disminuir la humedad y generación de elementos biológicos como el musgo, líquenes, etc.

g) En necesario realizar periódicamente un monitoreo y mantenimiento en forma periódica retirando el los elementos extraños depositados sobre los elementos líticos

\section{REFERENCIAS BIBLIOGRÁFICAS}

Espasa-Calpe. (1980). Enciclopedia Universal Ilustrada Europeo-Americana (Vol. 27). (N. d. Urgoti, Ed.) Madrid, España: Espasa Calpe.

Martínez Celis, D. (20 de 12 de 2018). monografias.com. Obtenido de https://www. monografias.com

Panofsky, E. (1985). El Significado en las Artes Visuales. (A. Editorial, Ed.) Madrid: Alianza Forma.

Ponte Rosalino, V. M. (2014). Arqueología en la Cordillera Negra del Callejón de Huaylas. Perú. Lima, Perú: Minera Barrick Misquichilca.

Ponte Rosallino, V. M. (1 de 11 de 2009). Universidad de Wisconsin Milwaukee. (vmponte@uwm.edu, Ed.) Andean Past 9, 131-175. Recuperado el 29 de diciembre de 2012, de https://digitalcommons.library.umaine.edu/andean_past/vol9/ iss $1 / 10$

RAE. (2014). Diccionario de la Lengua Española, Vigesimotercera edición. (R. A. Española, Editor) 


\section{SOBRE EL AUTOR}

\section{Donal Gutiérrez Espínola}

Profesor de arte y abogado egresado de la UNT; egresado de la Maestría en Gestión Cultural Patrimonio y Turismo de la Universidad San Martín de Porres y de la Maestría en Ciencias con mención en Conservación de Patrimonio Edificado de la Facultad de Arquitectura, Urbanismo y Artes de la Universidad Nacional de Ingeniería. Con cursos de especialización a nivel nacional e internacional. Ingreso en 1974 como conservador y restaurador de bienes muebles del Instituto Nacional de Cultura - La libertad, y como conservador de la Huaca Pucllana, Miraflores Lima a partir de 1982, laborando en varias años y temporadas. Ha participado como conservador arqueológico en diferentes proyectos a lo largo y ancho del país. En estos últimos años ha laborado como conservador en la Dirección de Gestión de Monumentos de la DGPA - Ministerio de Cultura-Lima. Actualmente desarrolla cursos teóricos - prácticos de conservación del patrimonio cultural arqueológico inmueble. 